\title{
The Effects of Two-Year College on the Labor Market and Schooling Experiences of Young Men
}

\author{
June, 1997 \\ (First Draft November, 1994) \\ Comments Welcome \\ Brian J. Surette \\ Federal Reserve Board \\ Washington, DC \\ bsurette@frb.gov
}

\begin{abstract}
In 1994 , nearly 40 percent of all college students attended two-year colleges. This study uses 12 years of data for young men from the NLSY to examine (1) the labor market returns to two-year college, (2) whether attendance at a two-year college helps students to transfer to four-year college, and (3) whether reducing the cost of college would alter attendance by enough to affect wages or income. I find that the returns to two-year college credits are large and positive (on the order of 7 to 10 percent), and that a student does not need to complete an associate's degree to enjoy these benefits. Degree completion further raises wages and income. Examining the transfer role of two-year colleges, I find that one year of two-year credits has the same effect on subsequent four-year college attendance as one year of four-year credits, suggesting that the transfer role is quite important. Finally, reducing tuition is shown to raise attendance by enough to raise average wages and earnings modestly. These results are based on a Full Information Maximum Likelihood framework in which discrete factor random effects address the potential bias introduced by unobserved heterogeneity.
\end{abstract}

Tom Mroz at the University of North Carolina provided considerable assistance in writing this paper. This research was supported by a grant from the American Educational Research Association which receives funds for its "AERA Grants Program" from the National Science Foundation and the National Center for Education Statistics (U.S. Department of Education) under NSF Grant \#RED-9255347. Opinions reflect those of the author and do not necessarily reflect those of the granting agencies or the Federal Reserve Board. 


\section{Introduction}

Over the last thirty years, two-year colleges have become an increasingly important part of the American post-secondary educational system. In 1994 nearly 40 percent of all college students attended two-year colleges (5.5 million students), up from only 21 percent ( 1.5 million students) in 1967. In fiscal 1994, federal and state governments spent $\$ 10.6$ billion financing two-year colleges. Despite these trends, only a handful studies have demonstrated that two-year college attendance directly benefits students. The most compelling evidence thus far is presented in Kane and Rouse [1995a, 1995b], who report that a year of two-year college provides wage returns on par with a year of four-year college. This study reexamines the effects of two-year college attendance using a more general modelling framework. Using full information maximum likelihood (FIML), I explore the causes of two-year and four-year college attendance, whether two-year college attendance affects the probability of subsequently attending a four-year college, as well as how attending either type of school affects wages and annual earnings. Moreover, the methodology I use allows me to estimate how attendance might change in response to policy changes that affect the cost of attendance. Equally important, I am able to quantify the labor market effects of those changes.

The methodology employed here addresses the possibility that previous estimates of the wage returns to two-year college are biased by unobserved variables. This point warrants further emphasis because of the huge literature that has evolved to address unobserved variables bias in standard wage regressions. It seems reasonable to ask whether unobserved variables affect estimates of the returns to two-year college attendance, as well. To address this concern, I estimate the returns to two-year and four-year college attendance using a discrete factor random effects estimator [Heckman and Singer, 1984] and full information maximum likelihood (FIML). The model is estimated using data from the 1979-1990 waves of the National Longitudinal Survey of Youth (NLSY). I focus on young men only for simplicity ${ }^{2}$.

The results from this study confirm that young men who attended two-year college substantially improved their subsequent wages. The estimated return to one year of two-year college credits is 9.6 percent--which is more than twice the return reported in Kane and Rouse. I estimate that

1 Figures from the 1996 Digest of Education Statistics, tables 170 and 325.

2 Women are excluded due to modelling complexities introduced by the fertility decision. Responsibilities related to fertility may fall disproportionately on women, and may make the causes and consequences of college attendance differ by gender. 
a 25 year old with one year of two-year credits would earn $\$ 850$ (7.5 percent) more per year than an otherwise similar high school graduate (all dollar figures are in 1987 dollars). Possession of an associate's degree is not required to enjoy these benefits, though having one does raise income further. A 25 year old worker with two years of two-year credits and an associate's degree is predicted to earn $\$ 1,970$ (17.1 percent) more per year than an otherwise similar high-school graduate. One year of fouryear credits is estimated to increase annual earnings by $\$ 1,450$ (12.8 percent) at age $25,{ }^{3}$ while possession of a bachelor's degree raises this differential to $\$ 6,620$ (58.7 percent) per year.

The estimated wage returns to college credits are 10 percent to 50 percent smaller when based on a model that does not address unobserved variables bias, though they are still positive and significant. The smaller estimates would still lead to the conclusion that both two-year and four-year college attendance have considerable labor market value. However, goodness of fit tests strongly favor the higher, discrete factor random effects estimates.

In addition to improving labor market outcomes, two-year colleges are shown to play an important role as intermediaries between the completion of high school and attendance at a four-year college. Each year of two-year college credits is predicted to raise both the probability of attending four-year college and the number of four-year credits completed each year. Possession of an associate's degree raises the probability of attending a four-year college further still. As four-year college attendance will also raise subsequent earnings, the overall effect of two-year attendance may be even larger than the dollar figures given above.

The FIML approach allows me to explore whether changes in tuition policy could affect college attendance or labor market outcomes significantly. A simulated a 50 percent reduction in twoyear and four-year tuition would raise both two-year and four-year college attendance rates by 1 to 3 percentage points, and would raise wages and annual earnings by 1 to 2 percentage points. These moderate gains in schooling, wages, and earnings are primarily attributable to increases in two-year college attendance. They suggest that policies designed to reduce the direct cost of college attendance could improve moderately the schooling levels and economic well-being of young men.

This paper proceeds as follows: Section 2 provides a brief overview of the NLSY data and the results from a preliminary analysis of those data. Section 3 describes the problem of unobserved variables and presents a FIML model that addresses this problem. Section 4 outlines the results from

3 The income effect of four-year college is larger than two-year college due to differences in the predicted number of hours worked. 
the FIML model. Section 5 describes results from simulations of changes in tuition policies. Section 6 summarizes and concludes the paper.

\section{The National Longitudinal Survey of Youth}

Data from the National Longitudinal Survey of Youth (NLSY) are used to estimate the causes and consequences of two-year college attendance. The NLSY, which began in 1979, collects extensive information about the schooling, labor market experiences, and background characteristics of young people. The original sample consisted of 12,686 men and women between the ages 14 and 21, most of whom have been reinterviewed annually. By focusing on such young individuals, the NLSY has been able to obtain detailed information about a wide variety of schooling experiences, and the survey allows total credits earned at two- and four-year colleges to be separately identified for each individual. Further, the panel is long enough to identify the distinct effects each type of schooling has on subsequent schooling, employment, and wages.

This study uses the first twelve waves from the NLSY, covering schooling and employment outcomes during the 1978-1989 calendar years. The military sub-sample (1,280 individuals), which the NLSY discontinued after 1984, was excluded from the final data, as were the economically disadvantaged non-black and non-Hispanic sample (1,643 individuals) and the female sample (4,926 individuals). ${ }^{4}$ To ensure that all post-secondary schooling decisions are observed, individuals who turned 18 before 1979 are excluded (1,635 individuals). Details about how the final sample was selected are provided in appendix one. The final sample consists of 3,202 individuals and 31,632 person years. The variables used in this analysis are defined in table 2.1 The mean characteristics for this sample are described in table 2.2. To give the reader a flavor for outcomes, table 2.2 also describes mean characteristics for 25 year olds in the sample. ${ }^{5}$

College attendance is defined in this paper by whether or not an individual earned any two- or

4 The economically disadvantaged group is excluded because their assignment to this group is based on a highly variable characteristic--family income. It is unclear what effect such a group would have on estimates from unweighted regressions that do not condition on family income.

5 Unweighted sample means are presented. The NLSY does not provide sample weights appropriate for a sample that excludes the military and economically disadvantaged non-black, nonHispanic sample. In the multivariate analysis that follows, dummy variables that identify different subsamples are used to address the influence of sample composition. The multivariate results can, therefore, be interpreted as applying to the overall population. 
four-year credits in a given year. ${ }^{6}$ Table 2.2 reveals that 7.9 percent of the sample attended two-year college and 18.5 percent attended four-year college at some point between 1978 and 1989. By age 25, 83.0 percent of the sample had completed high school, 6.7 percent had earned an associate's degree, and 15.9 percent had earned a bachelor's degree. These figures are largely consistent with attendance and degree completion rates published by the U.S. Department of Education (DOE) ${ }^{7}$ The unusually low bachelor's degree completion rate stems from the over-representation of black and Hispanic men in these NLSY data; black and Hispanic men are about half as likely as white men to complete a bachelor's degree (but are nearly as likely as white men to complete an associate's degree). ${ }^{8}$ Leigh and Gill [1997] report similar degree completion rates using the NLSY data.

Figure 2.1 graphs the age-attendance profiles at each type of college for high-school graduates. Two-year college attendance peaks at age 20 at 14.4 percent; four-year college attendance peaks at age 18 at 28.1 percent. $^{9}$ Figure 2.1 also shows the probability of attending four-year college, conditional on having previously attended a two-year college. After age 21, students who attended two-year college are much more likely than the total population of high school graduates to attend a four-year college. This evidence is consistent with the notion that a primary contribution of two-year colleges is to help high-school graduates make the transition from high-school to four-year college. This intermediary, or academic transfer, role is an important consideration for evaluating the overall contributions of two-year colleges.

The histograms in figures 2.2 and 2.3 show the distributions of total two-year and four-year credits completed as of 1989--the last year for which college credit data in the NLSY were observed. Other studies that use the NLSY, including Kane and Rouse [1995a] and Leigh and Gill [1997], have

${ }^{6}$ Appendix one describes in detail how the college credit data were assembled.

7 The 1996 Digest of Education Statistics reports that between 1978 and 1989, 25 percent to 31 percent of 18- to 24-year-olds attended either a two- or a four-year college (table 182, p. 189). Table 9 (p.18) reports that 7.6 percent of men aged 25 to 29 years have an associate's degree and 24.5 percent have a bachelor's (or higher) degree.

81996 Digest of Education Statistics, tables 10 and 256, pages 19 and 283.

9 The 1996 Digest of Education Statistics reports that 46.7 percent of recent male high-school graduates attended college in 1980. The small differences between the NLSY college attendance rates and the DOE's figures derive partly from differences in sample composition and partly from differences in the ways these figures are calculated. The DOE uses administrative enrollment records for recent high-school graduates, while the NLSY rates are based on self-reported education levels for all high-school graduates. 
based their conclusions on a hierarchy of schooling categories, rather than total completed credits. The more detailed college credit data used here should help to identify more precisely the labor market value of college attendance. The figures show that about one-third of two-year college students complete fewer than 30 credits (hereafter, 30 credits and one year's worth of credits will be used interchangeably). This is not surprising given the open admissions policies these school pursue, their low tuition, and the desire many students have to transfer to a four-year college. Figure 2.3 shows that nearly 80 percent of four-year students complete more than 30 credits. The notable spike at two years of two-year credits and four-years of four-year credits probably reflects the credit requirements for degree completion at the two types of schools. ${ }^{10}$

To illustrate the payoffs in the labor market of two-year and four-year college attendance, figure 2.4 graphs the age profiles of median average hourly earnings for 5 mutually exclusive groups of workers. Workers are divided according to their educational backgrounds as described in table 2.3. Figure 2.4 shows that after age 23 workers who attended either type of college (but did not earn a degree) have wages 6 percent to 8 percent higher than workers who never attended college. Degree completion raises wages further still: Workers with an associate's or a bachelor's degree earn, respectively, up to 30 percent and 39 percent more than high-school graduates. Figure 2.5, which graphs the median annual income for each education group, shows similar trends in earnings differentials after age 23 .

For comparison to previous work using the NLSY, the second column of table 2.3 presents estimates from a regression of $\log$ wages on the set mutually exclusive education categories discussed earlier. The equation is estimated using individuals who were at least 25 years old. The estimates indicate that having attended a two-year college raises wages by 10.3 percent. Possessing an associate's degree raises wages by 13 percent. Having attended four-year college does not affect wages significantly, but possessing a bachelor's degree raises wages by 25.6 percent. ${ }^{11}$

Again, for comparison to previous results, I estimated a pooled regression across age groups. The same set of exogenous explanatory variables described above were used, in addition to a new,

10 Despite the fact that these credit data are based on self-reports, figures 2.2 and 2.3 are strikingly similar to those displayed in Kane and Rouse (figure 1, p. 603), which were based on transcript reported data from a different survey conducted 10 years earlier (the NLS-72). Based on this comparison, it does not appear that respondents systematically over- or under-reported credits. conclusions.

11 Age specific regressions of wages or annual earnings would lead to qualitatively similar 
more complete, set of human capital measures. Instead of using the six education dummies defined earlier, continuous measures of credits earned at two-year college and at four-year college, years of labor market experience, years of vocational or on-the-job training were used. ${ }^{12}$ In addition, dummy variables for the completion of high school, an associate's degree, and a bachelor's degree are used. ${ }^{13}$ This specification identifies the extent to which credits, degrees, and labor market experience contribute to the earnings differentials displayed in figures 2.4 and 2.5 ; it allows us to assess the relative values--in terms of wages--of both types of college attendance, labor market experience, and training.

The estimates (table 2.4) demonstrate that a year's worth of credits at either type of college and a year of labor market experience all raise wages between 4 percent and 6 percent. One cannot, in fact, reject the hypothesis that one year of two-year credits, one year of four-year credits, and one year of labor market experience raise wages equally. ${ }^{14}$ Completing an associate's degree raises wages nearly 7 percent, though this parameter is estimated imprecisely; completing a bachelor's degree raises wages about 21 percent. $^{15}$

Both sets of estimates are roughly similar to those reported in Kane and Rouse (1995a). ${ }^{16}$ Differences probably stem either from changes in the structure of compensation between the mid to late seventies and the mid to late eighties or from the fact that individuals in my NLSY sample are 1 to 4 years younger than their samples. Also, their NLS-72 data does not allow them to include high school dropouts in their analysis. Nonetheless, the OLS estimates reported here are qualititatively and quantitatively similar to theirs.

12 Labor market experience is the sum of hours worked in past years. Individuals were defined to be working if they reported earning any income during a calendar year and reported the number of hours they worked. Individuals who earned more than 15 credits in a calendar year are treated as nonworkers; this is to avoid having summer jobs obscure the effects of more career-oriented labor market experience.

${ }^{13}$ The dummy variables for high school and college completion are not mutually exclusive.

14 The hypothesis that these three parameters are equal generates an F-statistic of 0.27 . The critical value for rejecting this hypothesis at the 95 percent confidence level is 19.5 .

15 The percentage increase in wages attributable to a dummy variable in a log-linear specification is calculated by taking the anti-log of the dummy variable's parameter estimate and subtracting one.

16 The model presented in table 2.3 replicates the regression presented in the first column Kane and Rouse's table 3. The model described in table 2.4 replicates the regression presented in the third column of their table 2 . 
Although the estimates described in this section tell a compelling story about the value of twoyear and four-year college attendance, the broader wage returns literature suggests that the labor market returns to schooling may be biased by unobserved variables such as ability, motivation, and intelligence. Previous researchers have incorporated scores on the Armed Forces Qualification Test (AFQT)--a measure of ability and intelligence--to control for unobserved variables that may be correlated both with schooling and wages. The regressions described above include AFQT score, which do differ on average by education group. However, even with AFQT on the right hand side, based on a Hausman test one may reject the hypothesis that the human capital measures are uncorrelated with the disturbance term in the wage equation, suggesting that the coefficient estimates reported above and in previous studies are biased. ${ }^{17}$ I use a random effects estimator--described in the next section--to address the unobserved variables problem.

\section{Modeling Framework}

The returns to two-year college attendance could theoretically be estimated using any one of several techniques that address unobserved variables bias. Perhaps the most straightforward method with which economists have addressed such bias is instrumental variables (IV). This method, however, generates imprecise (and implausible) estimates of the parameters in the wage equation using these NLSY data. ${ }^{18}$ Limited information methods, such as IV, are known to be relatively inefficient among multiple-equation models because in the estimation of any one equation they ignore information that could be obtained from other equations. ${ }^{19}$

With twelve time periods, wage returns could also be estimated using fixed-effects techniques. However, fixed-effects models may be inappropriate for estimating the effects of schooling on wages because parameter estimates are identified only by individuals who work while enrolled in school, or

17 The omitted variables (OV) version of the Hausman test was used. This test involves including instruments on the right-hand side of the wage equation and testing their joint significance with an $f$ test. Several sets of instruments were used, all of which were lagged values (i.e. values realized for ages 18 through 22) of exogenous variables that could be used to explain college attendance. The instruments included tuition at two-year and four-year colleges, the unemployment rate, and parents' education. The results of these tests varied, depending on the instruments included in the regression. However, the p-values were generally under 10 percent, and were as low as 1.3 percent.

18 IV estimates that use tuition as an instrument (not reported) had very large standard errors.

19 Greene (p. 602). 
by individuals who work before and after enrolling. Such individuals may have wage changes that are very different from the rest of the work force. Estimates of returns to schooling from fixed-effects models based on them may be misleading.

This study uses a random-effects estimator to overcome the limitations of both instrumental variables and fixed-effects techniques. The random-effects method provides consistent parameter estimates only if the covariates on the right hand side of the wage equation are exogenous. I circumvent the exogeneity requirement by modelling each schooling and employment outcome, and by estimating these outcomes jointly with wages in a FIML framework. The equations describing each of the modelled outcomes are presented below. Besides providing information useful for estimating the wage returns to attendance at two-year and four-year colleges, estimates from these decision equations provide information about the determinants of college attendance. This information is used in section 5 to simulate how schooling and labor market outcomes might be affected by changes in college tuition.

\subsection{The Human Capital Decision Model}

The main question being addressed in this paper is how college attendance would affect the subsequent labor market and schooling outcomes of a high school graduate. To properly address this question using a FIML framework requires that the alternative human capital activities that might compete for his time be modelled jointly with wages. A very attractive feature of these NLSY data is that it contains information about a wide range of post-secondary activities, allowing such a model to be estimated.

The wage each worker earns is assumed to reflect the productive capacity of his accumulated schooling, training, experience, and other productive characteristics. I use a standard 'Mincerian' formulation of the log of wages to describe these relationships.

$$
\ln (w)=\gamma_{1} \text { juntot }_{t}+\gamma_{2} \text { sentot }_{t}+\gamma_{3} \text { exper }_{t}+\gamma_{4} \text { trtot }_{t}+X_{t}^{*} \gamma_{5}+e_{w t}^{*}
$$

The right hand side includes detailed measures of completed schooling. The vector $\mathrm{X}_{1}$ measures other productivity-related variables and demographic characteristics. The error vector $\mathrm{e}_{\mathrm{wt}}$ measures 'noise' and unobservable variables, such as ability, motivation, and taste for work.

The following outcomes are modelled and estimated jointly with wages: whether or not an individual completes an additional year of high school (HS) (conditional on having not yet graduated), 
whether or not he works (work), the number of hours worked (hours) during the year, whether he attends two-year college (juncol) and/or four-year college (sencol), the number of two-year credits (cred2) and/or four-year credits (cred4) earned during the year. I also model training participation and the number of hours trained, but omit these equations to save space. With the exception of military experience, the model describes most of the post-secondary educational outcomes young men face.

The decision equations, given below, are based on expected utility maximization--individuals are assumed to attend school or to work only if such activities raise the present discounted value of lifetime utility. They approximate the difference between lifetime utility with participation in a particular activity and lifetime utility without participation in that activity using a polynomial function of explanatory variables. ${ }^{20}$

20 This paper makes no assumptions about the structure of preferences, except that they are twice differentiable, quasi-concave, and separable across time. 


$$
\begin{aligned}
& H S_{t}=\theta_{1} \text { school }+X_{t}^{*} \theta_{2}+e_{0 t}^{*} \\
& \text { work }_{t}=\delta_{1}^{j} \text { juntot }_{t}+\delta_{2} \text { sentot }_{t}+\delta_{3} \text { exper }_{t}+\delta_{4} \text { trtot }_{t}+X_{t}^{*} \delta_{5}+e_{1 t}^{*} \\
& \text { hours }_{t}=d_{1} \text { juntot }{ }_{t}+d_{2} \text { sentot }_{t}+d_{3} \text { exper }_{t}+d_{4} \text { trtot }_{t}+X_{t}^{*} d_{5}+e_{1 t} \\
& \text { juncol }{ }_{t}=\alpha_{\mathrm{r}} \text { juntot }_{t}+\alpha_{2} \text { sentot }_{t}+\alpha_{3} \text { exper }_{t}+\alpha_{4} \text { trtot }_{t}+X_{t}^{*} \alpha_{5}+e_{2 t}^{*} \\
& \text { cred2 }{ }_{t}=a_{\mathrm{P}} \text { juntot } t_{t}+a_{2} \text { sentot }{ }_{t}+a_{3} \text { exper }{ }_{t}+a_{4} \text { trtot }{ }_{t}+X_{t}^{*} a_{5}+e_{2 t} \\
& \text { sencol }_{t}=\beta_{1} \text { juntot }_{t}+\beta_{2} \text { sentot }_{t}+\beta_{3} \text { exper }_{t}+\beta_{4} \text { trtot }_{t}+X_{t}^{*} \beta_{5}+e_{3 t}^{*} \\
& \text { cred4 }_{t}=b_{\mathrm{I}} \text { juntot }_{t}+b_{2} \text { sentot }{ }_{t}+b_{3} \text { exper }{ }_{t}+b_{4} \text { trtot }_{t}+X_{t}^{*} b_{5}+e_{3 t}
\end{aligned}
$$

Individual ' $i$ ' subscripts have been omitted. The vector $X_{t}^{*}$ includes all the variables in $X_{t}$ (from the wage equation) plus variables that affect utility but not wages. ${ }^{21}$ The inclusion of variables in these decision equations that are excluded from the wage equation--for example college tuition--help to identify the model. As in the wage equation, these disturbance terms in include unobserved variables that may be correlated with accumulated human capital.

\subsection{Empirical Model}

21 Theoretically, human capital decisions are based on current exogenous variables that affect utility and expectations about the future values of these variables. Expectations about the future, however, may be formed based on past realizations. Thus, current human capital decisions are probably based on an information set that includes the current and lagged values of all the exogenous variables that affect utility. Decision rules that incorporate large numbers of lagged variables would be difficult to estimate. I therefore approximate the equations given by (2) as polynomial functions of current human capital stocks and current exogenous variables. 
Each of these post-secondary outcome is modeled in each of the twelve years in which each person can be observed (for some individuals, some outcomes are irrelevent and are not modelled-high school or college attendance for a bachelor's degree holder, for example). The model is not identified without imposing some restrictions on the covariance between the disturbance terms in each decision equation. Estimating this system of equations one equation at a time requires the assumption that the covariance between any two disturbance terms is zero. The estimation technique used in this study is more flexible: Two discrete random factors control for the contemporaneous and acrossperiod correlations among disturbance terms in the decision equations. This technique, described in appendix two, provides consistent and efficient estimates of the labor market effects of schooling, training, and labor market activities.

\section{Estimation Results}

This section describes the estimated effects of two-year college attendance on subsequent labor market and schooling outcomes. I model three specific labor market outcomes: average hourly earnings (wages), the probability of working at all each year (employment), and the number of actual hours worked in each year (hours). These three components are discussed in turn, and are then combined to describe the effects of two-year college attendance on their product--total expected annual earnings. Next I turn my attention to the two-year and four-year college attendance decisions. There are two components to the attendance decision at each type of school: whether to attend at all in a given year (a zero-one outcome) and, if so, how many credits to earn while in attendance that year. I discuss in sequence the two-year attendance decisions and the four-year attendance decisions. Keep in mind that, although I describe these estimation results sequentially, all the outcomes are estimated jointly. I conclude the section by examining the fit of the estimated model using a variety of common goodness of fit criteria.

\subsection{The Wage Equation}

The first step in calculating expected annual earnings is to obtain estimates from the log wage equation given by equation (1). ${ }^{22}$ As all college students in these data completed a high school degree,

22 Included as covariates are AFQT test score, completed two-year credits (linear and quadratic), completed four-year credits (linear and quadratic), years of vocational training, years of labor market experience (linear and quadratic), and dummies for possession of high school, associate's, or bachelor's degrees (not mutually exclusive). These equations also include a large number of background and 
the estimated coefficients on the college credit and degree completion variables reflect how these college variables raise wages relative to those earned by a high school graduate who did not attend college, holding other covariates, including experience, constant. These estimates are presented in the first column of table 4.1. However, because high school graduates tend to trade-off labor market experience for college credits, such ceteris paribus estimates may be misleading. I therefore also compare predicted wages for workers with different schooling levels and experience levels. These effects--which I will refer to as "adjusted" effects to distinguish them from ceteris paribus effects-allow one to gauge the relative profitability (in terms of wages and annual income) of two-year and four-year college attendance and labor market work. The adjusted returns are presented graphically in figure 4.1 .

The ceteris paribus estimates reported in column one (table 4.1) show that a high school graduate earns 4.0 percent more than a high school dropout. ${ }^{23}$ The marginal returns to the first and second years of two-year college credits are 9.6 percent and 7.5 percent, respectively. College students who complete an associate's degree earn an additional 8.6 percent wage premium. ${ }^{24}$ Both the returns to two-year credits and the return to an associate's degree are much larger than Kane and Rouse's estimates based on the NLS-72. They report that the return to each year of two-year credits is 4.1 to 4.7 percent and that possession of an associate's degree does not affect wages significantly.

The marginal return to one year of four-year credits is 6.5 percent, though this effect diminishes as the number of credits increases; the fourth year of four-year credits is estimated to have

demographic characteristics: age (linear and quadratic), a time trend, the local unemployment rate, parents education, dummies for black or Hispanic ethnicity, dummies that account for oversamples of black and Hispanic men, and a dummy variable for whether the respondent lives in an urban area. The complete set of parameter estimates are available from the author upon request.

${ }^{23}$ In a log wage equation, the percentage increase in wages induced by discrete outcomes is calculated by taking the anti-log of the coefficient estimate and subtracting one. The percentage increase in wages caused by each continuous outcome is calculated using the linear and quadratic terms, regardless of their significance level.

24 The effects of degree completion come in addition to the effects of accumulated credits. Some researchers [Kane and Rouse, 1995a,b] have 'zeroed-out' credits for degree completers. This assumes that the return to credits for degree completers is the negative of the estimated return to credits for degree non-completers. A test that interactions between each type of credits and each type of degree using these data indicates that the returns to college credits are slightly higher for degree recipients, but that the differences are not statistically significant. Possessing a bachelor's degree still raises wages substantially and significantly. The effects of possessing an associate's degree on wages falls somewhat and only becomes significant at the 10 percent level. 
almost no effect on wages. Completion of a bachelor's degree, however, which usually occurs at then end of the fourth year, raises wages by an additional 27.0 percent. The first year of labor market experience is predicted to raise wages by 8.3 percent, but this effect diminishes so that each year beyond the second has a lower marginal return than one year's worth of credits at either type of college.

To better gauge the relative value of college credits and labor market work, figure 4.1 displays adjusted wage-age profiles based on the estimates reported in Table 4.1. These are stylized profiles that illustrate how the hourly earnings of a high school graduate vary with regard to specific postsecondary schooling and labor market decisions; they compare the predicted wage paths of individuals possessing the age-specific mean characteristics for all variables except schooling and experience. ${ }^{25}$

The figure shows that students who complete 30 credits at either type of college have higher wages than high school graduates who never attended college. At age 20, workers with one year of two-year college credits are predicted to have wages 8.6 percent higher than high school graduates, holding all other characteristics (except experience) constant. By age 25, this differential has increased to 9.6 percent and is predicted to continue rising with age. Similarly, a worker with one year of fouryear credits would earn wages 6.3 percent higher than a high school graduate at age 25 . For high school graduates facing the college attendance decision at age 18, attending either a two-year or a four-year college is predicted to raise future wages by more than the labor market experience they would otherwise have obtained

According to these adjusted estimates, large positive wage gains are realized regardless of whether or not a worker possesses a college degree; however, figure 4.1 shows that either an associate's or bachelor's degree raises wages further still. At age 25, workers with 2 years of two-year credits and an associate's degree earn wages about 26 percent higher than high school graduates who never went to college. Workers with 4 years of four-year credits and a bachelor's degree earn wages 32 percent higher. The adjusted estimates make clear that individuals facing the college attendance decision can earn substantially higher wages if they attend either two-year or four-year college-regardless of whether they earn a degree. Moreover, these wage gains are realized very early in the career--as early as age 19 or 20 for workers with one year's worth of credits--and the wage gains grow

${ }^{25}$ For high school graduates, the level of experience used to predict earnings is the mean level observed for workers at each age. For workers who attended college, the experience level used is the mean experience for workers in their age group, less the mean experience for workers at the age they leave college. 
larger with age and experience.

The estimated wage returns to both two-year and four-year college credits are smaller if the $\log$ wage equation is estimated using OLS instead of the discrete factor method. However, those estimates (not reported here) still show that both the ceteris paribus returns and the adjusted returns are positive and significant: one year of two-year credits has an adjusted return 3.2 percent. Similarly, one year of four-year credits has an adjusted return of 4.1 percent. An associate's or a bachelor's degree would raise wages by 12.9 and 26.2 percent, respectively. Thus, regardless of whether or not the discrete factor method controls for unobserved variables bias, the hypothesis that the returns to two-year credits are positive cannot be rejected. This is reassuring, given the important role labor market returns play in assessments of education policies designed to increase college attendance rates. However, differences in the magnitudes of these estimated effects are large. Evidence from my goodness of fit tests, reported at the end of this section, indicates that the discrete factor estimates should be preferred.

\subsection{The Employment Decision}

The second component used to calculate expected annual income is the decision to work at all during each year, which I model as a function of schooling, experience, and other covariates. There are several reasons why schooling in general, and two-year credits in particular, may affect the probability of working at all in a given year. For example, employers may value the vocational skills taught at two-year colleges. Attendance may therefore provide access to jobs in industries or occupations where the risk of being fired or laid off is lower, or where the probability of being hired (or re-hired) is higher. However plausible such explanations are, it is not possible to empirically verify them in this study. Nonetheless, they provide some intuition for why the employment outcomes may differ for individuals with different schooling levels.

Column two (table 4.1) presents the estimates for the employment decision equation using the discrete factor method. These ceteris paribus estimates show that high school graduates are more likely to work than individuals who do not complete high school, while neither type of college degree seems to affect the employment decision significantly. The largest and most significant determinant of employment (among human capital measures) is years of labor market experience. Each additional year of labor market experience raises the probability of employment significantly, albeit at a diminishing rate. The effect of each year of two-year or four-year college credits on the probability of employment are also positive and significant. 
In percentage terms the adjusted effects of college credits on the probability of employment are quite large, considering that over 90 percent of non-students work in any given year. At age 25, for example, workers with one year's worth of two-year credits are 0.8 percentage points more likely to work than otherwise similar high school graduates. Workers with one year of four-year credits are 0.5 percentage points more likely to work. Clearly account should be taken of these differentials; though they would translate into relatively modest increases in expected annual income (for a worker an earnings potential of $\$ 15,000$ per year, the differential would be $\$ 75$ to $\$ 120$ ), they do contribute to observed differences in expected annual earnings between high school graduates and workers who attended college. Over a working life, such differences could amount to a noteworthy sum.

\subsection{Estimating Hours Worked}

The third component that will go into calculating expected annual income is total annual hours worked. Estimates from the annual hours worked equation are reported in column 3 (table 4.1). Note that this is a reduced form equation, and it is not possible in this framework to identify the causes of differences in annual hours worked among different education groups. Such differences could arise, as noted above, if workers with different education levels entered industries or occupations with different hours of work standards. I leave aside the question of precisely how education affects hours worked and focus solely on the end result that actual hours worked are different. These effects can, therefore, be interpreted a combination of labor supply and labor demand responses to education and experience.

Estimates from column 3 imply a substantial hours response to completed schooling, particularly with respect to labor market experience, four-year college credits, and possession of a bachelor's degree. Most of the men in the sample work close to 2000 hours by age 25 . The adjusted estimates indicate that one year of two-year credits reduces by 50 the number of hours worked per year compared to a high school graduate. This difference is due entirely to the fact that the high school graduate has more experience. One year of four-year credits raises annual hours worked by an adjusted 105 hours per year. The adjusted effect of possessing a bachelor's degree are also very large -- on the order of 270 hours per year. ${ }^{26}$

The raw data and regression estimates based on OLS indicate that there are real differences in the average number of hours worked across education groups. However, the predicted annual hours

${ }^{26}$ For bachelor's degree holders, the effects of each year of experience and each year of four-year credits are smaller than for non-degree holders; they are attenuated by statistically significant interaction terms (not reported). 
worked for four-year college graduates with more than 4 or 5 year's of labor market experience appear to be too high. ${ }^{27}$ This problem is probably due to the relatively small sample of individuals in their late twenties. When making comparisons of predicted annual income (discussed below) I will focus on workers 26 years old and younger. Estimated annual hours worked for these younger individuals are much more consistent with average hours observed in the data. Income comparisons based on them should be unaffected by sample size limitations.

\subsection{Summary of Labor Market Effects}

The overall effect of two-year and four-year college on economic well-being may be best characterized by predicted annual income--the product of predicted hourly wages, annual hours worked, and the probability of employment. Figure 4.2 displays graphically the expected age-earnings profiles for workers with different education levels (and potentially different experience levels), as predicted by the adjusted estimates from the discrete factor method. Dollar figures are calculated in 1987 dollars.

According to figure 4.2, a 25 year old worker with one year of two-year credits would have an expected annual income about $\$ 850$ (7.5 percent) higher than an otherwise identical high school graduate who did not attend college. A 25 year old worker with one year of four-year credits would have an expected annual income nearly $\$ 1450$ (12.8 percent) higher than an otherwise identical high school graduate. For younger workers these differentials would be smaller, though they are always positive.

A worker who graduated from college would earn substantially more than a worker who never attended college. Figure 4.2 shows that a 25 year old worker who completed 2 years of two-year college and an associate's degree would have an expected annual income $\$ 1930$ (17.1 percent) higher than otherwise similar high school graduates with no further education. Completing 4 years of fouryear college and a bachelor's degree raises this differential to $\$ 6,620$ (58.7 percent) per year. ${ }^{28}$

2727 year old four-year college graduates are predicted to work an adjusted 2460 hours per year, or 47 hours per week, 52 weeks per year.

${ }^{28}$ The differentials are somewhat smaller when the predictions are based on OLS and Probit models. At age 25, one year of two-year credits is predicted to increase annual income by $\$ 650$ (5.1 percent). Workers with one year of four-year credits have predicted annual income exceeding high school graduates' by $\$ 520$ (4.1 percent). Differentials among degree completers based on the OLS/Probit models are smaller in magnitude than the discrete factor estimates suggest, but they are still substantial. 
These education earnings differentials are realized at a cost. College tuition must be paid, and hours worked must be reduced -- potentially to zero -- while enrolled in college. Assume, for example, that the opportunity cost of one year of two-year college is $\$ 10,000$, and that the pecuniary benefits are $\$ 850$ per year. An internal rate of return equal to 8.5 percent would equate opportunity cost and discounted earnings (assuming infinite working lives). For four-year college students, the comparison is even more favorable: if their opportunity cost were $\$ 10,000$, and their earnings differential were $\$ 1,450$, an internal rate of return equal to 14.5 percent makes college attendance for a single year worthwhile in present discounted value terms. ${ }^{29}$ These figures make clear that both twoyear and four-year college attendance can be very good investments. Completing a college degree only adds to their attractiveness.

\subsection{The Decision to Attend College}

The pecuniary benefits of two-year college attendance are not realized solely in direct increases in wages and earnings. As discussed earlier, these schools may also serve as intermediaries that help high-school graduates make the transition to eventual enrollment in four-year college. To emphasize the importance of this transfer role, this section presents estimates of the college attendance decision equations. The estimates show that two-year credits raise the probability of attending fouryear college. In fact, one cannot reject the hypothesis that a year of two-year college credits and a year of four-year credits raise equally the probability of subsequently attending four-year college. To the extent that two-year attendance helps high school graduates enroll in and succeed in four-year college, the direct pecuniary benefits described above will understate the overall value of these schools. The section begins with a brief description of the determinants of two-year college attendance, before focusing on the role of these schools in the four-year attendance decision. ${ }^{30}$ The results from the college credit equations are also presented in Table 4.2 , but are not discussed.

29 Two-year college students are more likely to work and work more hours than four-year college students. The opportunity costs of four-year college attendance are, therefore, somewhat higher than for two-year college attendance. As such, the implied discount rates for two-year and four-year college attendance are probably more similar than the figures given in the text.

30 One may be concerned that some students might have difficulty getting accepted to four-year college, and that the model should account for this barrier to entry. Manski and Wise (1983) conclude that most students would be accepted at some college or university, though it may not be their first choice school. Admittance restrictions probably play at most a small role in the decision to attend college at all. 
The first column in Table 4.2 report estimates of the two-year college attendance decision equation--whether or not a high school graduate attends two-year college in each year. The estimates show that completed two-year credits raise the probability of continuing two-year attendance, but at a diminishing rate. Once an individual completes just over three semesters worth of two-year credits, the marginal effect on the probability of attending two-year college becomes negative.

One commonly used price of college--particularly for individuals on the margin--is the tuition at public colleges in their state of residence; such schools almost always cost less than private or outof-state public colleges. The estimates show that the probability of attending two-year college is significantly lower for individuals in states with relatively high tuition at public two-year or four-year schools.

It could be argued that these tuition effects are capturing something other than price responses. For example, individuals or families that value education may migrate to states that heavily subsidize education. In that case, the correlation between tuition and college attendance would be spurious, rather than causal. It is compelling, however, that the estimated tuition effects all have the "right" sign -- especially if my hypothesis about the two-year college's transfer role is correct. In particular, the cross price effects in the two college attendance decision equations suggest that higher four-year tuition reduces two-year attendance significantly. This would be expected only if subsequent four-year college attendance complemented two-year attendance. By contrast, the cross-price effect from the four-year college attendance decision (column 3) indicate that higher two-year tuition induces higher four-year attendance. This suggests that two-year college attendance is a substitute for four-year college attendance, but that the converse is not true.

Reducing tuition at public two-year colleges by $\$ 500$ is predicted to raise the probability of attending two-year college; for 19 year olds, their attendance rates are predicted to rise from 11 to 14 percent in response to the tuition reduction. Kane [1997] reports price-sensitivities roughly similar in magnitude for two-year college attendance. Note that these are partial equilibrium effects. Colleges may not have enough empty seats to accommodate such an increase, and the labor market may not be able to absorb such a large number of college-educated workers at the going wage. Nonetheless, this predicted increase is substantial and suggests that policy-makers may have the ability to raise enrollment substantially by reducing tuition.

The third column (table 4.2) reports estimates from the four-year college attendance equation. Completed two-year credits have a significant, positive impact on the probability of attending four-year college. One cannot reject the hypothesis that one year of credits at either type of school raise equally 
the probability of subsequently attending a four-year college. A 20 year-old individual with mean characteristics of the sample and either one year of two-year credits or one year of four-year credits has, respectively, a 33 percent and a 34 percent probability off attending four-year college. These two effects are statistically indistinguishable. Moreover, possession of an associate's degree further raises the probability of attending four-year college. ${ }^{31}$

Two interpretations of thse effects seem plausible: First, two-year college attendance may help students who would otherwise not have gone to a four-year college to transfer to and succeed in fouryear college. Second, individuals who have decided to acquire a bachelor's degree may find it less expensive to attend two-year college for a year or two before moving on to four-year college. Twoyear colleges generally have lower tuition than four-year college, and public four-year colleges generally allow a significant portion of two-year credits to count toward the requirements for a bachelors degree. In this case, the correlation between two-year credits and four-year attendance would be spurious, rather than causal. The model does not distinguish between these two interpretations, though both suggest a positive role for two-year colleges. It seems likely that the estimated effects of credits combines them.

Reducing four-year college tuition by $\$ 500$ is estimated to raise the probability of four-year attendance by about two percentage points at age 19. If both four-year and two-year tuition were reduced by $\$ 500$, the two-year tuition effect (which has opposite sign, and is larger in magnitude) would dominate, resulting in a net reduction in four-year attendance of about one percentage point. As noted above, however, reductions in four-year tuition are predicted to cause substantial increases in two-year attendance. The decline in four-year attendance may be attenuated if account were taken of the predicted increased two-year attendance rates. In the next section I present simulations indicating that four-year attendance would actually rise if both two-year and four-year tuition were reduced as a result of the two-year college transfer effect.

Estimates based on probit versions of the college attendance decision equations differ in only two important ways from the estimates described thus far. First, the effects of tuition on both twoyear and four-year college attendance are somewhat smaller. However, they retain their signs and in 3 out of 4 cases remain statistically significant. Only the own- price effect of four-year tuition becomes

31 Brint and Karabel [1989] present evidence that two-year colleges (particularly their administrators) have historically attempted to divert students from their pursuit of a four-year college education. The estimates presented here indicate that students are not so easily dissuaded from their educational ambitions. 
statistically insignificant. Second, the effects of two-year credits on four-year attendance are smaller, but remain statistically significant. Thus, two-year credits may not have exactly the same effect as four-year credits on four-year attendance, but they do have a large, statistically significant effect that ought to be considered in assessments of two-year schools.

\subsection{Model Choice}

Three criteria were used for evaluating how well the estimated models describe the data: Inspection and comparison of predicted and actual outcomes, likelihood-based measures of explanatory power, and classical chi-square goodness-of-fit tests.

To give a flavor for the models' predictive power, figures 4.3 and 4.4 graph the observed and predicted age profiles for two-year and four-year college attendance and for wages and annual income. The predictions are model-based in the sense that labor market experience, college credits, and vocational training are updated according to lagged predictions of the model at each age. ${ }^{32}$ For example, if an 18 year-old is predicted to attend two-year college, and he is predicted to earn 30 twoyear credits while in attendance, then his predicted decisions at age 19 will be based, in part, on the 30 credits he was predicted to have earned in the preceding year. ${ }^{33}$ Completed four-year credits, labor market experience, vocational training, and college degrees are similarly updated in each year over the entire 12 year panel. Such an updating scheme greatly increases the complexity of the model's predictions but provides the most realistic description of how the model works.

As figure 4.3 shows, the model predicts the general age-college attendance profiles fairly well, though it does miss some of the severe curvature of these profiles during the prime college-going years. This limitation could be addressed by using more flexible age controls, for example a vector of age dummies. However, the computational cost of such a change is prohibitive. The quadratic in age with a linear spline after age 24 used here represents a parsimonious compromise between

32 The predictions are based on monte carlo integration (using 50 simulations) over the estimated distribution of unobserved heterogeneity.

33 There is a small initial conditions problem relating to years of high school completed. The simulations take as given the number of years of schooling each individual had completed as of their first interview. No consideration is given to why individuals of the same age have different levels of schooling. Part of the reason for this, no doubt, relates to local restrictions on the age of first admittance to kindergarten. A more worrisome explanation concerns differences in ability and motivation that are not addressed in the model. 
computational cost and predictive power. ${ }^{34}$

Figure 4.4 presents graphically the observed and predicted annual income (left scale) and predicted wage (right scale) age-profiles. The model appears to predict wages quite well across all ages. Except for the downtick in observed wages at age 28, predicted and observed wages differ only slightly. The model does tend to overpredict annual income -- in large part because it overpredicts the probability of working (not shown) in each year. In general--and despite the extreme complexity of the updating mechanism for the human capital measures--both figures demonstrate that the model does a good job describing schooling and labor market outcomes.

Table 4.3 presents the log-likelihood function values of several different versions of the FIML model. It indicates that the function value increases dramatically when the discrete factor method is used, instead of OLS and probit. This provides some evidence that the heterogeneity controls improve the explanatory power of the model. However, as Heckman and Walker [1993] point out, the test of random-effects models against Probit or OLS models is being performed at the boundary of the parameter space and is, therefore, not valid. Nonetheless, the dramatic increase is at least suggestive of improved explanatory power.

The improvement in the likelihood function argues in favor of including the heterogeneity controls. Coupled with the Hausman test (discussed in section 2) indicating that the human capital measures are endogenous, it seems that the discrete factor estimates reported in tables 4.1 and 4.2 more accurately describe the causal effects of two-year college attendance than the OLS and Probit models. However, as likelihood-based tests are not strictly valid for comparing non-nested models, I calculated the classical chi-square goodness of fit statistic [Heckman, 1984; Andrews, 1988] to determine whether incorporating semi-parametric controls for unobserved heterogeneity is supported. These goodness of fit tests are reported in table $4.4 .^{35}$

In most cases, the chi-square test lead us to reject the hypothesis that either the OLS/Probit models or the discrete factor random-effects models describing these data well. The 95 percent critical

34 A model estimated with a cubic in age produced unsatisfactory results. It substantially overpredicted attendance at both types of colleges after age 25 .

35 The reported tests do not include the correction outlined in Heckman [1984] and Andrews [1988] to account for parameter estimation. Theoretically, the statistics reported in the table are, therefore, biased against rejecting the null that the model is correctly specified. However, Heckman and Walker [1995] report that the correction makes only a very small difference in the value of the chi-square statistic. They suggest that the uncorrected test statistics are adequate. 
value for these test is 7.82--most of the chi-square statistics exceed this threshold by a considerable margin. The two exceptions are the wage equation and the four-year credit equation. The wage equation from the discrete factor model cannot be rejected with 95 confidence level, nor can the fouryear credit equation from the OLS model. Moreover, the tests based on the heterogeneity-corrected models are almost all lower than the non-heterogeneity corrected models. In particular, the discrete factor labor supply equation could not be rejected at the 90 percent confidence level. Such results provide strong evidence that the random-effects models used here perform better than their OLS and Probit counterparts.

The large number of rejections points out one of the limitations of the classical test (and of non-nested tests in general): nested tests such as the likelihood ratio, wald, and lagrange multiplier tests all measure themselves against specific (nested) alternative models. The classical chi-square test measures itself against how well it predicts what is actually observed in the data. It is a very onerous metric against which to evaluate one's model. The fact the random-effects wage equation cannot be rejected on this basis is strong evidence, not only that heterogeneity controls significantly improve the fit of the model, but that the estimates from the heterogeneity-corrected wage equation describe more accurately the true returns to two-year college attendance.

\section{Policy Simulations}

As reported in Table 4.2, the point estimates from the model indicate that both two- and fouryear college attendance are sensitive to tuition. This section examines whether changes in tuition would alter college attendance enough to affect labor market outcomes--in particular, wages and earnings. To that end, the estimates from the discrete factor model are used to simulate the effects of a fifty percent reduction in both two-year and four-year college tuition on the employment and schooling decisions made by the young men in the sample. These simulations are based on the same methodology used to compare observed and predicted outcomes presented in figures 4.3 and 4.4. The simulation results are presented in figures 5.1 and 5.2.

For high school graduates between the ages 18 and 24, two-year college attendance rates are predicted to rise by 2 to 3 percentage points in the face of the tuition reduction. Four-year college attendance rates are predicted to rise by close to 1 percentage point. Total two-year and four-year credits are also predicted to increase (not shown); based on the increase in completed credits the model predicts that 9.7 percent of all 25 year olds will have an associate's degree, up from 7.3 percent before the tuition reduction. The percentage of 25 year olds with bachelor's degrees is estimated to 
rise from 15.2 percent to 16.0 percent. ${ }^{36}$ Once again, two-year college attendance is shown to be more sensitive to tuition reductions than four-year attendance.

In another study that examines the educational role of two-year colleges, Rouse [1995] examines how increasing the accessibility of two-year college (either by building new campuses nearby or reducing tuition) would affect total schooling completed. She finds that lower tuition at and shorter travel distances to two-year college would raise total years of schooling, but would not affect the probability of completing a bachelor's degree. To test whether my model generates similar predictions, I ran simulations in which only two-year college tuition was reduced. The results (not shown) demonstrate that the overall effects on educational attainment of reducing two-year tuition alone are positive: four-year college attendance would fall by a fractional percent, and the number of bachelor's degrees completed would remain virtually unchanged. However, two-year college attendance, completed two-year credits, and the number of new associate's degrees earned would rise by about 1 to 2 percentage points.

I next examine whether the increases in college attendance and degree completion induced by an across-the-board reduction in tuition at both two-year and four-year colleges would affect labor market outcomes. Figure 5.2 shows that reducing tuition at both two-year and four-year colleges would have some modest positive effects. The right scale, which graphs average wages by age, shows that the reduction in tuition would raise average wages by roughly 1 percent at age 25 . Note that this increase in average wages derives almost entirely from increases in human capital because tuition has been excluded from the wage equation. As experience remained virtually unchanged and vocational training actually fell in response to the tuition reduction, one can attribute most of the increase in average wages to increases in college credits and degrees.

If only two-year tuition were reduced, the model predicts that wages, earnings, and employment would remain virtually unchanged (they would increase by a tiny amount). Coupled with the negative effect of four-year tuition on two-year attendance and the positive effect of two-year credits on four-year attendance, this suggests that the opportunity to transfer credits to a four-year college is an extremely important feature of two-year colleges. It reinforces my conclusion that the

36 Because degree completion is not explicitly modelled, the simulations use a 'rule of thumb' to assign degrees based on the number and type of college credits completed. The thresholds vary (to reflect variations observed in the sample), but an individual needs at least 112.5 total credits to earn a bachelor's degree, of which 67.5 must be earned at a four-year college. Similarly, an individual needs at least 52.5 total credits to earn an associate's degree, of which 37.5 must be from a two-year college. 
transfer role two-year colleges play is a crucial component to the overall value of these schools.

The left scale of figure 5.2 graphs average predicted annual earnings before and after the tuition reduction at both two-year and four-year colleges. At age 25, average annual earnings are predicted to rise by $\$ 554$ (2.9 percent) in response to the tuition reduction. This increase is larger in percentage terms than the predicted increase in average wages because tuition is included in the labor supply and employment equations. The effects of the tuition reduction on annual income includes those induced by higher employment rates and slightly higher annual hours worked.

It should again be noted that these simulations are based on a partial-equilibrium model. If there is limited availability of seats in college classrooms, beds in college dormitories, and jobs for college graduates in the labor market, these predicted increases in attendance would be attenuated to some extent. In the face of such constraints, the effects reported here should be viewed as long-term predictions. However, if there is a need to build more dormitories and more academic buildings to accommodate increases in desired college attendance, then the cost of those expansions should be included in an analysis of the costs and benefits of the proposed policy change.

It is not possible in this framework to model specifically the various policy changes that have been proposed to increase college attendance. However, these simulations shed important light on the sensitivity of college attendance to changes in the cost of attendance. These results can be interpreted as approximating reductions in the cost of college attendance through whatever form is ultimately decided on, if any. One can reasonably conclude from these estimates and simulations that reducing the cost of college through tax incentives or cheaper loans would raise college attendance and improve wages and earnings modestly. Whether any of the proposed policy changes can pay for themselves, however, would depend on how broadly they were applied to the population of high school graduates. In the end, such policy decisions may need to be made on more than the costs and benefits described here.

\section{Summary and Conclusion}

Overall, the results from this analysis suggest an important, positive role for two-year colleges in shaping the educational and employment outcomes of young men in the U.S. The paper demonstrates that the labor market benefits of two-year college attendance are much larger than previously reported and are realized very early in mens' careers. Moreover, the paper identifies a second, important effect of two-year college attendance, namely their role in helping students to transfer to four-year college. Both the academic transfer role and the labor market effects should be 
considered when assessing the contributions of two-year colleges.

Two-year college attendance is estimated to raise wages and expected annual income -- even for students who do not complete an associate's degree. Students with one year of two-year credits are estimated to earn $\$ 850$ (7.5 percent) more than an otherwise similar high school graduate at age 25. One year of four-year credits is estimated to raise annual income by $\$ 1450$ (12.8 percent). Possession of an associate's or bachelor's degree further raise income by, respectively, $\$ 1,930$ (17.1 percent) and $\$ 6,620$ (58.7). These earnings gains are substantial, and if they are sustained over the working life (and the model predicts they would actually increase with age) they imply a considerable improvement in economic well-being.

In addition to these labor market effects, each year of two-year credits raises the probability that a student will subsequently attend four-year college and raises the number of four-year credits earned. In fact, one cannot reject the hypothesis that one year of credits at either type of school raise equally the probability of subsequently attending a four-year college. These estimates highlight the importance of the role two-year colleges play, both in the labor market and as intermediaries between high school to four-year college. Simulations indicate that reducing tuition at either two-year or fouryear college would increase college attendance, increase degree completion rates, and perhaps most importantly, increase expected wages and annual income modestly.

The estimation framework described in this paper addresses a potentially serious shortcoming in the literature---the lack of research in which the effects of unobserved heterogeneity are addressed. The discrete factor random effects model controls, to the extent that it can, for the bias unobserved heterogeneity may introduce into estimates of the value of two-year college attendance. The discrete factor estimates indicate that the labor market returns to two-year college attendance estimated using OLS actually understate their true return. The specification tests strongly favor the discrete factor models over models that do not address unobserved heterogeneity.

Because the model is estimated on a panel of data I am able to examine how changes in college tuition might affect college attendance and labor market outcomes over the early course of adulthood. One would expect these effects to be relatively modest. However, the simulations demonstrate that reductions in college tuition on the order of $\$ 300$ and $\$ 700$ per year would not only raise two-year college attendance, but would translate into moderate wage and earnings gains in the longer term. Wages would increase by roughly one percent in response to the tuition reduction -- an increase that is substantially attributable to increases in two-year college credits and associate's degrees earned. Average annual income is predicted to rise by more than 2 percent, for example, at age 25 (an 
earnings differential of $\$ 554)$ as a result of the tuition change. These results suggest that education policy-makers have some ability to alter the college attendance decisions of youth and that any such changes could have noteworthy effects on wages and earnings. 


\section{$\underline{\text { References }}$}

American Association of Community and Junior Colleges. Community College Fact Book. New York: Collier MacMillan Publishers, 1988.

Andrews, Donald. "Chi-Square Diagnostic Tests for Econometric Models." Journal of Econometrics 37 (1988): 135-156.

Becker, Gary S. Human Capital: A Theoretical Analysis with Special Reference to Education. New York: Columbia Univ. Press, 1963.

Ben-Porath, Yoram. "The Production of Human Capital and the Life Cycle of Earnings." The Journal of Political Economy 75 (1967): 352-365.

Blinder, Alan S. and Yoram Weiss. "Human Capital and Labor Supply: A Synthesis." Journal of Political Economy 84:3 (1976): 449-471.

Breneman, David and Susan Nelson. Financing Community Colleges: An Economic Perspective. Washington, DC: The Brookings Institution, 1981.

Brint, Stephen and Jerome Karabel. The Diverted Dream: Community Colleges and the Promise of Educational Opportunity in America, 1900-1985. New York: Oxford University Press, 1989.

Cameron, Stephen and James Heckman. "The Nonequivalence of High School Equivalents." Journal of Labor Economics 11:1 (1993): 1-47.

Card, David and Daniel Sullivan. "Measuring the Effect of Subsidized Training Programs on Movements in and out of Employment." Econometrica 56 (1988): 497-530.

Eckstein, Z. and K. I. Wolpin. 1989. "The Specification and Estimation of Dynamic Stochastic Discrete Choice Models." Journal of Human Resources 24:562-98.

Green. William H. Econometric Analysis, Englewood Cliffs, NJ: Prentice Hall, 1993.

Gritz, Mark. "An Empirical Analysis of the Effect of Training Programs on Employment." Journal of Econometrics 57:1-3 (1993): 21-51.

Grubb, Norton. "The Varied Economic Returns to Postsecondary Education." Journal of Human Resources 28:2 (1993): 365-382.

Heckman, James J. and Burton Singer. "A Method for Minimizing the Impact of Distributional Assumptions in Economic Models for Duration Data." Econometrica 52 (1984): 271-320.

Heckman, James J. "The $\mathrm{X}^{2}$ Goodness of Fit Statistic for Models with Parameters Estimated from Microdata." Econometrica 52 no.6 (1984): 1543-1547. 
Heckman, James J. and James Walker. "Using Goodness of Fit and Other Criteria to Choose Among Competing Duration Models: A Case Study of Hutterite Data." Sociological Methodology 1987, ed. C. Clogg. Washington. D.C.: American Sociological Association.

Kane, Thomas J. "Rising Public College Tuition and College Entry: How Well do Public Subsidies Promote Access to College." (1995) NBER Working Paper No. 5164.

Kane, Thomas J. and Cecilia E. Rouse. "Labor Market Returns to Two- and Four-Year College". American Economic Review 85:3 (1995a): 600-614.

Kane, Thomas J. and Cecilia E. Rouse, "Comment on W. Norton Grubb, 'The Varied Economic Returns to Post-secondary Education: New Evidence from the Class of 1972'." Journal of Human Resources, Winter 1995, 30(1), pp.205-21.

Leigh, Duane and Andrew Gill. "Labor Market Returns to Community Colleges." Journal of Human Resources 32:2 (1997): pp 334-353.

Lynch, Lisa M. "Private Sector Training and the Earnings of Young Workers." American Economic Review 82:1 (1992): 299-312.

MaCurdy, Thomas E. "Interpreting Empirical Models of Labor Supply in an Intertemporal Framework with Uncertainty." Longitudinal Analysis of Labor Market Data. Eds. James Heckman and Burton Singer. Cambridge: Cambridge University Press, 1985. 111-153.

Manski, Charles and David Wise. College Choice in America. Cambridge: Harvard University Press, 1983.

Mincer, Jacob. Schooling, Experience and Earnings. New York: NBER, 1974.

Mroz, Thomas A. and David K. Guilkey. "Discrete Factor Approximations for Use in Simultaneous Equation Models with Both Continuous and Discrete Outcomes." (1993) University of North Carolina mimeo.

Mroz, Thomas A. and David Weir. " Estimation of Controlled Stochastic Processes with an Endogenous State Space: Approximations, Functional Forms, 'Heterogeneity,' Taste Variation and an Application to Age at Marriage and Life Cycle Fertility Control in France Under the Ancien Regime" (1993) University of North Carolina and NORC mimeo.

Rouse, Cecelia. "Democratization or Diversion: The Effect of Community Colleges on Educational Attainment", Journal of Business and Economic Statistics, April, 1995, 13(2), pp 217-224.

United States Department of Education. The Digest of Education Statistics. Government Printing Office, Washington DC, 1996.

Willis, Robert J. and Sherwin Rosen. "Education and Self-Selection." Journal of Political Economy 87:5 (1979), S7-S36. 


\section{Appendix One}

\section{Sample Composition}

The sub-sample of men who turned 18 after 1978 contains 3202 individuals and 38,424 person-years. Keeping track of college attendance was quite complicated and required that interview non-participants be dropped after their first missed interview. This requirement eliminated 4772 person-years. As long as attrition is random, it will not bias estimates of the effects of schooling. Item non-response is more likely to cause bias. Individuals who attend college have many more opportunities for item-non response, due the detailed nature of the schooling questions in the NLSY. Systematically discarding these individuals would produce a sample which under represents college students. Missing values were therefore imputed based on information provided elsewhere in the survey.

I eliminated individuals reporting very large or very small values for their decision variables, or obviously inconsistent or unbelievable values. These filters eliminate anyone reporting average hourly earnings less than $\$ 0.50$ /hour or greater than $\$ 500$ /hour, or hours worked in excess of 3650/year. Also dropped are those who claim to complete more than 75 college credits or 4000 hours of vocational training in a single year, live in a labor market with an unemployment rate exceeding $50 \%$, or report having a college degree but never report attending college. Because this analysis compares the impacts of undergraduate education at two- and four-year colleges, individuals completing a graduate degree are also eliminated. These last filters eliminate 2020 person-years, leaving 3202 individuals and 31632 person-years in the final data set.

\section{Description of NLSY College Attendance and College Credit Variables}

As the author is unaware of any other research using the self-reported college credit data contained in the NLSY, a brief description of these data is provided here. During the $1984-1986$ and the 1988 - 1990 interviews, the NLSY asked high school graduates whether they had attended college, the name of each college attended, the dates of attendance at each, and the total number of credits earned at each. Colleges are identified by their unique Federal Interagency Committee on Education (FICE) code, making it possible to construct complete credit histories at each school for the entire 1978-1989 period. Two-year college credits are defined as those earned from schools offering the associate's degree as their highest degree. Four-year college credits are defined as those earned from schools offering at least a bachelor's degree. These degree data are obtained for each school from the Integrated Post-Secondary Education Data System (IPEDS) provided by the National Center for Education Statistics (NCES).

We restrict these data to reflect the structure of the educational system in the United States Only high school graduates older than 16 years of age are considered for college attendance. In addition, bachelor's degree completers are excluded from the college attendance equations. While a very small number of students do attend college prior to completing high school, allowing for this possibility causes estimation problems. Most notably, the impact of high school degree on college attendance swamps the estimated effects of other covariates -- and it is the impacts of these other covariates we are most interested in measuring. 
Appendix Two

\section{The Likelihood Function}

The decision equations described in the text are, for notational convenience, redefined in table A.1.

\begin{tabular}{|c|c|c|}
\hline \multicolumn{3}{|c|}{$\begin{array}{c}\text { Table A.1 } \\
\text { Variables as Defined in Likelihood Function }\end{array}$} \\
\hline & Symbol & Disturbance \\
\hline Employment during year (work) & $\mathrm{k}_{\mathrm{lt}}{ }^{*}$ & $\mathrm{e}_{1 \mathrm{t}}^{*}$ \\
\hline Annual hours worked (hours) & $\mathrm{k}_{\mathrm{lt}}$ & $\mathrm{e}_{1 t}$ \\
\hline Log average hourly earnings (lnwage) & $w_{1}$ & $\mathrm{e}_{\mathrm{wt}}$ \\
\hline Two-year college attendance (juncol) & $\mathrm{k}_{2 \mathrm{t}}{ }^{*}$ & $\mathrm{e}_{2 \mathrm{t}}^{*}$ \\
\hline Two-year credits earned (cred2) & $\mathrm{k}_{2 \mathrm{t}}$ & $e_{2 t}$ \\
\hline Four-year college attendance (sencol) & $\mathbf{k}_{3 \mathrm{t}}^{*}$ & $\mathrm{e}_{3 \mathrm{t}}^{*}$ \\
\hline Four-year credits earned (cred4) & $\mathbf{k}_{3 \mathrm{t}}$ & $e_{3 t}$ \\
\hline Training participation (train) & $\mathrm{k}_{4 \mathrm{t}}^{*}$ & $\mathrm{e}_{4 \mathrm{t}}^{*}$ \\
\hline Annual hours trained (training) & $\mathrm{k}_{4 \mathrm{t}}$ & $\mathrm{e}_{4 \mathrm{t}}$ \\
\hline High school attendance (attend) & $\mathrm{k}_{0 \mathrm{t}}^{*}$ & $\mathrm{e}_{0 \mathrm{t}}^{*}$ \\
\hline \multicolumn{3}{|c|}{$\begin{array}{l}\text { Note: The symbols that describe the discrete outcomes (work, juncol, sencol, train, attend) stand } \\
\text { for the continuous indices (i.e. the XB) that determine whether or not an individual participates in } \\
\text { an activity. }\end{array}$} \\
\hline
\end{tabular}

Two time-invariant, individual specific random factors, $\mu_{1}$ and $\mu_{2}$, are used to describe the influence of unobserved variables on the parameters in the schooling, training, employment, and wage equations. These 'permanent' factors are intended to address the bias introduced by unobserved variables that persist across time for each person, such as intelligence or motivation. ${ }^{37}$

More formally, the discrete factors are modeled as unobserved components of the disturbance terms in each equation. The terms $\mathrm{e}_{\mathrm{jt}}{ }^{*}, \mathrm{e}_{\mathrm{jt}}$, and $\mathrm{e}_{\mathrm{wt}}$ represent, respectively, disturbances in the participation equations, the intensity equations, and the wage equation:

37 Although it is tempting to regard $\mu_{1}$ and $\mu_{2}$ as measuring tangible, if unobserved, characteristics, in truth they are simply statistical tools for limiting the bias introduced by crossequation correlations among the error terms. It is not presumed that they actually measure any specific characteristic(s). 


$$
\begin{aligned}
& e_{j t}^{*}=\rho_{j}^{*} \mu_{1}+\theta_{j}^{*} \mu_{2}+v_{j t}^{*}, j=0, \ldots, 4 \\
& e_{j t}=\rho_{j} \mu_{1}+\theta_{j} \mu_{2}+v_{j t}, j=1, \ldots, 4 \\
& e_{w t}=\rho_{w} \mu_{1}+\theta_{w} \mu_{2}+v_{w t}
\end{aligned}
$$

The parameter vectors $\rho$ and $\theta$ measure outcome specific effects (that is, they vary from equation to equation) and the v's are assumed to be i.i.d. disturbances.

The person-specific conditional likelihood function describing employment, college, training, and wage outcomes in each year, conditional upon the specific values of the unobserved factors, is given by:

$$
L_{c t}\left(\mu_{1}, \mu_{2}\right)=f_{w}\left(e_{w t} \mid \mu_{1}, \mu_{2}\right){ }^{d} \prod_{j=0}^{4}\left\{p r\left(k_{j t}^{*}>0 \mid \mu_{1}, \mu_{2}\right) f_{j}\left(e_{j t} \mid \mu_{1}, \mu_{2}\right)\right\}^{d}{ }^{j t}\left\{p r\left(k_{j t}^{*} \leq 0 \mid \mu_{1}, \mu_{2}\right)\right\}^{1-d_{j t}}
$$

where the $\mathrm{f}_{\mathrm{m}}(),. \mathrm{m}=\mathrm{w}, 1, \ldots, 4$ are the density functions of the error terms in each of the decision equations. The $\mathrm{d}_{\mathrm{jt}}$ are dummy variables indicating whether the $\mathrm{k}_{\mathrm{ji}}{ }^{*}$ indicators are positive. The probability terms, denoted by 'pr(.)', are simply the cumulative distribution function for each decision's index function.

Because all the outcomes are independent, conditional on $\left(\mu_{1}, \mu_{2}\right)$, the influence of the unobserved variables may be removed by integrating the conditional likelihood function $\left(\mathrm{L}_{\mathrm{ct}}\right)$ over their respective distributions, $\mathrm{G}\left(\mu_{1}\right)$ and $\mathrm{H}\left(\mu_{2}\right)$. The discrete factor method, described in Heckman and Singer [1984], uses step-functions to approximate the distributions $G\left(\mu_{1}\right)$ and $H\left(\mu_{2}\right)$. This technique is more general than normal-based random-effects estimation because it does not impose on the data any specific distribution. Rather, the parameters of the distributions of unobserved factors are estimated jointly with the other parameters in the model. ${ }^{38}$ The discrete factor technique has the added advantage of parsimony; it replaces a multiple-dimensioned integral of the multivariate normal distribution with a multiple summation, making estimation less costly. The unconditional likelihood function $\left(\mathrm{L}_{\mathrm{u}}\right)$ is, therefore, simply a probability-weighted sum of conditional likelihood functions:

$$
L_{u}=\sum_{q=1}^{Q} P W_{1 q} \sum_{r=1}^{R} P W_{2 r} \prod_{t=1}^{T} L_{c t}\left(\mu_{1 q}, \mu_{2 r}\right) \text {. }
$$

There are $Q$ and $R$ mass points, respectively, in $G\left(\mu_{1}\right)$ and $H\left(\mu_{2}\right)$. The probability of observing particular mass points is $\mathrm{PW}_{1 \mathrm{q}}$ for $\mathrm{q}=1, \ldots, \mathrm{Q}$ and $\mathrm{PW}_{2 \mathrm{r}}$ for $\mathrm{r}=1, \ldots, \mathrm{R}$. The location of the mass points along the unit interval and their associated probabilities are estimated jointly with the rest of the coefficients in the model. ${ }^{39}$ This study uses $\mathrm{Q}=5$ and $\mathrm{R}=4$.

38 In a Monte Carlo analysis of the discrete factor technique, Mroz and Guilkey [1993] demonstrate that discrete factor models perform about as well as normal-based maximum likelihood estimators when the assumption of normality is valid, but perform better when the normality assumption is violated.

39 The consistency of the estimates from the discrete factor approach requires that $\mathrm{Q}$ and $\mathrm{R}$ go to infinity. Mroz and Guilkey (1993), however, demonstrate in a Monte Carlo study that a small number 


\section{Identification}

Identification of the parameters in this model derives from four sources. First, the model is estimated using panel data; multiple observations of each individual, both across time and across outcomes within any year, provide information that may be used to identify the parameters of interest and the distributions of unobserved factors. In a standard, normal-based random-effects model, for example, two observations of each individual are sufficient to secure identification. The model described in this section was estimated on up to twelve years of data, and up to ten outcomes per year for each person. The use of information from all equations and all time periods in the estimation of parameters for any one equation or time period is the mechanism by which FIML models achieve their efficiency relative to limited information models, such as instrumental variables.

Second, the model is identified by the exclusion of certain explanatory variables from each equation. As noted above in the description of the human capital decision equations, only current realizations of the exogenous variables affect current outcomes. Lagged exogenous variables affect current outcomes only through their influence on previous human capital decisions. Thus, for example, total two-year credits earned before the current year are determined by past realizations of tuition; lagged exogenous variables have no direct effect on current human capital decisions.

Third, functional form restrictions on the distributions of the discrete factors help identify the model. The magnitudes and locations of probability mass in the distributions $G\left(\mu_{1}\right)$ and $H\left(\mu_{2}\right)$ are derived from well-behaved, logistic functions. Each mass point $\left(\mu_{\mathrm{jk}}\right)$ is limited to the unit interval by the logistic function given by

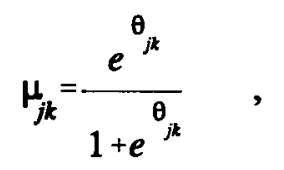

where the $\theta$ are the estimated parameters.

The probability weights are given a logistic form, as well. They are given by

$$
P W_{j k}=\frac{e^{\delta_{j k}}}{1+\sum_{q=2}^{Q} e^{\delta_{j q}}}, j>1,
$$

where the $\delta$ are the estimated parameters. For both the mass points and the probability weights, the logit form helps ensure a well-behaved optimization process by reducing the probability that heterogeneity parameters will be drawn from the boundary of the parameter space.

Finally, identification derives from restrictions on the covariance between the disturbance terms in any two decision equations. The estimation method employed here uses only two factors. A perfectly general 10-equation model would require 9 factors. By restricting the covariance matrix, it is possible that it biases estimates of the parameters of interest. Future work incorporating additional factors may help determine the magnitude of this potential source of bias.

of points of support appears to approximate well several different continuous distributions. 
Table 2.1

\begin{tabular}{|c|c|}
\hline Variable & Description \\
\hline Work & Dummy for employment status during any part of year \\
\hline Hours & Hours in paid employment for entire year (divided by 2000) \\
\hline Exper & Accumulated years of labor market experience \\
\hline Lnwage & Natural log of average hourly earnings \\
\hline Juncol & Dummy for two-year college attendance during any part of year \\
\hline Cred2 & Two-year credits earned during current year \\
\hline Juntot & Two-year credits accumulated prior to current year \\
\hline Sencol & Dummy for four-year college attendance during any part of year \\
\hline Cred4 & Four-year credits earned during current year \\
\hline Sentot & Four-year credits accumulated prior to current year \\
\hline Hsdeg & Dummy for having completed grade 12 \\
\hline Assoc & Dummy for possession of associate's degree \\
\hline Bach & Dummy for possession of bachelor's degree \\
\hline Attend & Dummy for enrolled in high school, conditional on having not yet completed grade \\
\hline Train & Dummy for participation in a training program during any part of year \\
\hline Trhours & Hours enrolled in training program during year (divided by 2000 ) \\
\hline Trtot & Hours enrolled in training, accumulated prior to current year (divided by 2000 ) \\
\hline School & Years of High School \\
\hline Age & Age of respondent, normalized by subtracting $13(14$ year olds have age $=1)$ \\
\hline Year & The number of years since 1977 \\
\hline Tui2 & Average tuition at public two-year colleges in the respondent's state of residence \\
\hline Tui4 & Average tuition at public four-year colleges in the respondent's state of residence \\
\hline Black & Dummy for part of black cross-section \\
\hline Hispanic & Dummy for part of Hispanic cross-section \\
\hline Overblk & Dummy for part of black oversample \\
\hline Overhsp & Dummy for part of Hispanic oversample \\
\hline AFQT & Armed Forces Qualification Test Score \\
\hline Urban & Dummy for residence in an urban area \\
\hline Unemp & Unemployment Rate in county (or non-metro part of state) of residence \\
\hline Mommiss & Dummy indicating mother's education level missing \\
\hline Momhgc & Mother's highest grade completed (zero if mommiss $=1$ ) \\
\hline Dadmiss & Dummy indicating father's education level missing \\
\hline Dadhgc & Father's highest grade completed (zero if dadmiss $=1$ ) \\
\hline
\end{tabular}


Table 2.2

Mean Characteristics of Entire Sample and of 25 Year Olds

\begin{tabular}{|c|c|c|c|c|c|c|}
\hline \multirow[t]{2}{*}{ Variable Name } & \multicolumn{3}{|c|}{ Whole Sample } & \multicolumn{3}{|c|}{25 Year Olds } \\
\hline & NOBS & MEAN & STD. & NOBS & MEAN & STD. \\
\hline WORK & 21078 & 0.835 & 0.371 & 2182 & 0.865 & 0.342 \\
\hline LNWAGE & 17599 & 1.789 & 0.693 & 1888 & 1.986 & 0.621 \\
\hline HOURS & 17599 & 0.861 & 0.382 & 1888 & 1.006 & 0.320 \\
\hline EXPER & 31632 & 1.530 & 2.315 & 2283 & 3.304 & 2.361 \\
\hline SCHOOL & 31632 & 11.08 & 1.405 & 2283 & 11.60 & 1.058 \\
\hline ATTEND & 12215 & 0.558 & 0.497 & 388 & 0.010 & 0.101 \\
\hline HSDEG & 31632 & 0.614 & 0.487 & 2283 & 0.830 & 0.376 \\
\hline JUNCOL & 17993 & 0.079 & 0.270 & 1570 & 0.029 & 0.167 \\
\hline CRED2 & 1425 & 0.557 & 0.385 & 45 & 0.662 & 0.471 \\
\hline JUNTOT & 31632 & 0.137 & 0.495 & 2283 & 0.276 & 0.699 \\
\hline ASSOC & 31632 & 0.031 & 0.173 & 2283 & 0.067 & 0.251 \\
\hline SENCOL & 17993 & 0.185 & 0.388 & 1570 & 0.052 & 0.221 \\
\hline CRED4 & 3328 & 0.799 & 0.415 & 81 & 0.752 & 0.518 \\
\hline SENTOT & 31632 & 0.450 & 1.208 & 2283 & 0.980 & 1.800 \\
\hline BACH & 31632 & 0.058 & 0.234 & 2283 & 0.159 & 0.366 \\
\hline TRAIN & 31632 & 0.102 & 0.303 & 2283 & 0.134 & 0.341 \\
\hline TRHOURS & 3227 & 0.229 & 0.264 & 307 & 0.189 & 0.262 \\
\hline TRTOT & 31632 & 0.099 & 0.328 & 2283 & 0.184 & 0.435 \\
\hline AFQT & 31632 & -0.051 & 2.234 & 2283 & 0.015 & 2.232 \\
\hline AGE & 31632 & 8.120 & 3.636 & 2283 & 12.00 & 0.000 \\
\hline BLACK & 31632 & 0.066 & 0.253 & 2283 & 0.067 & 0.250 \\
\hline HISPANIC & 31632 & 0.046 & 0.209 & 2283 & 0.046 & 0.209 \\
\hline OVERBLK & 31632 & 0.239 & 0.427 & 2283 & 0.240 & 0.427 \\
\hline OVERHSP & 31632 & 0.145 & 0.352 & 2283 & 0.141 & 0.349 \\
\hline URBAN & 31632 & 0.773 & 0.419 & 2283 & 0.774 & 0.418 \\
\hline UNEMP & 31632 & 7.739 & 3.135 & 2283 & 6.970 & 2.669 \\
\hline MOMMISS & 31632 & 0.065 & 0.247 & 2283 & 0.065 & 0.247 \\
\hline MOMHGC & 31632 & 10.17 & 4.110 & 2283 & 10.16 & 4.119 \\
\hline DADMISS & 31632 & 0.150 & 0.357 & 2283 & 0.148 & 0.355 \\
\hline DADHGC & 31632 & 9.49 & 5.332 & 2283 & 9.516 & 5.312 \\
\hline TUI2 & 31632 & 0.689 & 0.387 & 2283 & 0.909 & 0.418 \\
\hline TUI4 & 31632 & 1.370 & 0.620 & 2283 & 1.865 & 0.561 \\
\hline YEAR & 31632 & 6.038 & 3.407 & 2283 & 9.867 & 1.356 \\
\hline
\end{tabular}


Table 2.3

Mutually Exclusive Education Categories

\begin{tabular}{|c|c|c|}
\hline Variable Definition & $\begin{array}{c}(1) \\
\text { Percent of } \\
\text { Sample }\end{array}$ & $\begin{array}{c}(2) \\
\text { Estimated } \\
\text { Wage } \\
\text { Return }\end{array}$ \\
\hline Never completed high school & 0.24 & $-0.023(.040)$ \\
\hline High school graduates with no further education & 0.39 & omitted \\
\hline Attended two-year college only (no college degree) & 0.09 & $0.098(.046)$ \\
\hline $\begin{array}{l}\text { Attended four-year college and may have attended } \\
\text { two-year college (no college degree) }\end{array}$ & 0.11 & $0.042(.048)$ \\
\hline Earned an associate's degree & 0.05 & $0.122(.061)$ \\
\hline $\begin{array}{l}\text { Earned a bachelor's degree (may also have an associate's } \\
\text { degree) }\end{array}$ & 0.13 & $0.228 \quad(.043)$ \\
\hline Number of observations & 31,632 & 2461 \\
\hline \multicolumn{3}{|c|}{$\begin{array}{l}\text { Note: Standard errors in parentheses. } \\
\text { 1. Also included as covariates are were: AFQT score, age, age squared, year, black, Hispanic, } \\
\text { overblk, overhsp, urban, unemp, mommiss, momhgc, dadmiss, dadhgc, tui218, tui418, urban } 18 \text {, } \\
\text { unemp } 18 \text {, parttime, overtime. } \\
\text { 2. Only the latest observation of each individual was used in the estimation. }\end{array}$} \\
\hline
\end{tabular}

Table 2.4

Pooled Regression Estimates Based on Detailed Human Capital Measures ${ }^{1,2}$

\begin{tabular}{|c|c|c|c|c|c|c|c|}
\hline & $\begin{array}{l}\text { Two-Year } \\
\text { Credits }\end{array}$ & $\begin{array}{l}\text { Four-Year } \\
\text { Credits }\end{array}$ & $\begin{array}{l}\text { Vocational } \\
\text { Training }\end{array}$ & $\begin{array}{l}\text { Labor Mkt } \\
\text { Experience }\end{array}$ & $\begin{array}{l}\text { H.S. } \\
\text { Degree }\end{array}$ & $\begin{array}{l}\text { Assoc. } \\
\text { Degree }\end{array}$ & $\begin{array}{l}\text { Bach. } \\
\text { Degree }\end{array}$ \\
\hline $\begin{array}{l}\text { Parameter estimate } \\
\text { (standard error) }\end{array}$ & \multirow{2}{*}{$\begin{array}{l}0.052 \\
(.021) \\
\\
2461\end{array}$} & \multirow[t]{3}{*}{$\begin{array}{l}0.043 \\
(.013)\end{array}$} & \multirow[t]{3}{*}{$\begin{array}{l}0.090 \\
(.026)\end{array}$} & \multirow[t]{3}{*}{$\begin{array}{l}0.061 \\
(.006)\end{array}$} & \multirow[t]{3}{*}{$\begin{array}{l}0.026 \\
(.034)\end{array}$} & \multirow[t]{3}{*}{$\begin{array}{l}0.065 \\
(.057)\end{array}$} & \multirow[t]{3}{*}{$\begin{array}{l}0.191 \\
(.057)\end{array}$} \\
\hline Number of Obs. & & & & & & & \\
\hline Adjusted R-squared & .220 & & & & & & \\
\hline
\end{tabular}

Note: Standard errors in parentheses.

1. Also included as covariates were: AFQT score, age, age squared, year, black, Hispanic, overblk, overhsp, urban, unemp, mommiss, momhgc, dadmiss, dadhgc, tui218, tui418, urban 18, unemp18, parttime, overtime.

2. Only the latest observation of each individual was used in the estimation. 


\begin{tabular}{|c|c|c|c|}
\hline \multicolumn{4}{|c|}{$\begin{array}{c}\text { Table 4.1 } \\
\text { Labor Market Outcomes } \\
\text { Estimation Results Based on Discrete Factor Method }\end{array}$} \\
\hline Variable Name & $\begin{array}{c}(1) \\
\text { Log Wage }^{1}\end{array}$ & $\begin{array}{c}(2) \\
\text { Employment }^{2}\end{array}$ & $\begin{array}{c}\text { (3) } \\
\text { Annual Hours } \\
\text { 3,4 }\end{array}$ \\
\hline AFQT Score & $0.043(.005)$ & $0.017(.008)$ & $-0.010(.002)$ \\
\hline High School Degree & $0.039(.019)$ & $0.151 \quad(.032)$ & $0.044(.009)$ \\
\hline Completed 2-yr Credits & $0.118(.030)$ & $0.237(.031)$ & $-0.005(.006)$ \\
\hline Completed 2-yr Credits Squared & $-0.011 \quad(.010)$ & -- & -- \\
\hline Completed 4-yr Credits & $0.089(.018)$ & $0.194(.020)$ & $0.072(.004)$ \\
\hline Completed 4-yr Credits Squared & $-0.012(.003)$ &.- & -- \\
\hline Labor Market Experience & $0.093(.007)$ & $0.814(.018)$ & $0.132(.004)$ \\
\hline Labor Market Experience Squared & $-0.005(.001)$ & $-0.051 \quad(.002)$ & $0.009(.000)$ \\
\hline Completed Voc. Training & $0.050 \quad(.018)$ & $0.007(.040)$ & $-0.016(.008)$ \\
\hline Associate's Degree & $0.083(.033)$ & $0.050(.077)$ & $-0.003(.015)$ \\
\hline Bachelor's Degree & $0.240(.033)$ & $0.109(.081)$ & $0.191 \quad(.030)$ \\
\hline nobs & 17,599 & 21,078 & 17,599 \\
\hline \multicolumn{4}{|c|}{$\begin{array}{l}\text { Note: Standard errors in parentheses. } \\
\text { 1. The log wage equation also included as covariates age, age2, year, black, Hispanic, overblk, overhsp, } \\
\text { urban, unemp, mommiss, momhgc, dadmiss, and dadhgc. } \\
\text { 2. The employment equations include age } 3 \text {, tui2, and tui4, in addition to the variables in the wage equation. } \\
\text { 3. Total hours worked during the year is normalized by dividing the total by } 2000 \text {. } \\
\text { 4. The hours equation included tui2, tui } 4 \text {, and all the variables in the wage equation, with the exception of } \\
\text { the quadratic schooling variables and the age variables. Instead of quadratic age effects for all ages, this } \\
\text { equation uses a quadratic up to age } 24 \text {, and a linear spline thereafter. The hours equation also includes } \\
\text { interactions between sentot*bach and exper*bach, both of which were negative and significant. }\end{array}$} \\
\hline
\end{tabular}




\begin{tabular}{|c|c|c|c|c|}
\hline \multicolumn{5}{|c|}{$\begin{array}{c}\text { Table } 4.2 \\
\text { College Attendance Decisions }\end{array}$} \\
\hline & $\begin{array}{c}\text { (1) } \\
\text { 2-yr College } \\
\text { Attendance }^{1}\end{array}$ & $\begin{array}{c}(2) \\
\text { 2-yr Credits } \\
\text { Earned }^{2,3}\end{array}$ & $\begin{array}{c}\text { (3) } \\
\text { 4-yr College } \\
\text { Attendance }^{1}\end{array}$ & $\begin{array}{c}(4) \\
\text { 4-yr Credits } \\
\text { Earned }^{2,3}\end{array}$ \\
\hline AFQT Score & $0.048 \quad(.011)$ & $0.006 \quad(.007)$ & $0.455(.025)$ & $0.032(.006)$ \\
\hline Completed 2-yr Credits & $1.677(.062)$ & $0.073(.016)$ & $0.662(.045)$ & $0.155(.015)$ \\
\hline Completed 2-yr Credits Sq. & $-0.512(.026)$ & -- & -- & -- \\
\hline Completed 4-yr Credits & $-0.197 \quad(.028)$ & $-0.013(.021)$ & $0.864(.051)$ & $0.057(.009)$ \\
\hline Completed 4-yr Credits Sq. & - & -- & $-0.180(.010)$ & -- \\
\hline Labor Market Experience & $-0.126(.013)$ & $-0.066(.009)$ & $-0.177(.025)$ & $-0.047(.011)$ \\
\hline Complete Voc. Training & $-0.018(.047)$ & $0.039 \quad(.029)$ & $0.194(.073)$ & $0.026(.025)$ \\
\hline 2-yr Tuition & $-0.261 \quad(.058)$ & $0.025 \quad(.035)$ & $0.318 \quad(.091)$ & $-0.013(.030)$ \\
\hline 4-yr Tuition & $-0.105(.048)$ & $0.021 \quad(.032)$ & $-0.158 \quad(.066)$ & $0.007(.021)$ \\
\hline Unemployment Rate & $0.026(.005)$ & $-0.002(.003)$ & $0.022(.007)$ & $-0.002(.002)$ \\
\hline Associate's Degree & $-0.281 \quad(.074)$ & $-0.065(.043)$ & $0.249 \quad(.086)$ & $-0.038 \quad(.032)$ \\
\hline nobs & 17993 & 1425 & 17993 & 3227 \\
\hline \multicolumn{5}{|c|}{$\begin{array}{l}\text { Note: Standard errors in parentheses. } \\
\text { 1. In addition to the variables listed, the Juncol \& Sencol equations include year, black, Hispanic, overblk, } \\
\text { overhsp, urban, unemp, tui2, tui4, mommiss, momhgc, dadmiss, dadhgc, and the quadratic/spline in age } \\
\text { included in the labor supply equation. } \\
\text { 2. The dependent variable is credits earned during the current year divided by } 30 \text {. } \\
\text { 3. The credit equations include all the other exogenous variables in the attendance decision equations, except } \\
\text { that a quadratic in age replaces the quadratic/spline in age. }\end{array}$} \\
\hline
\end{tabular}




\begin{tabular}{|l|l|l|}
\hline \multicolumn{3}{|c|}{ Comparison of Likelihood Function Values ${ }^{1}$} \\
\hline Model Tested & Log-Likelihood Function Value & $\begin{array}{l}\text { Increase in the Number of } \\
\text { Estimated Parameters }\end{array}$ \\
\hline OLS \& Probit & $-51,008$ & 245 \\
\hline $\begin{array}{l}2 \text { factors, } 4 \text { \& } \\
3 \text { mass points }\end{array}$ & $-49,421$ & 15 \\
\hline $\begin{array}{l}2 \text { factors, } 4 \text { \& } \\
4 \text { mass points }\end{array}$ & $-49,381$ & 2 \\
\hline $\begin{array}{l}2 \text { factors, } 5 \text { \& } \\
\text { mass points }\end{array}$ & $-49,371$ & 2 \\
\hline $\begin{array}{l}\text { 1. The Akaike Information Criterion suggests that a model is preferred if the increase } \\
\text { in the likelihood function exceeds the increase in the number of parameters. }\end{array}$ \\
\hline
\end{tabular}




\begin{tabular}{|c|c|c|c|}
\hline \multicolumn{4}{|c|}{$\begin{array}{c}\text { Table } 4.4 \\
\text { Chi-Square Goodness of Fit Test } \\
\text { Based on } 1000 \text { simulations }\end{array}$} \\
\hline Dependent Variable & $\begin{array}{l}\text { Cell } \\
\text { Threshold }\end{array}$ & $\begin{array}{l}\text { Test Based on OLS or } \\
\text { Probit }\end{array}$ & $\begin{array}{l}\text { Test Based on Discrete } \\
\text { Factor Model } \\
2 \text { factors, } 5 \text { and } 4 \text { mass } \\
\text { points }\end{array}$ \\
\hline Employment & n.a. & 39.9 & 39.8 \\
\hline High School Attendance & n.a. & 203.7 & 128.9 \\
\hline Two-Year College Attendance & n.a. & 542.3 & 422.9 \\
\hline Four-Year College Attendance & n.a. & 552.9 & 401.1 \\
\hline Training Participation & n.a. & 148.3 & 123.5 \\
\hline Hourly Wage & $\$ 7.25$ & 15.3 & $2.0 * *$ \\
\hline Annual Hours Worked & 2,100 & 19.0 & $8.5 *$ \\
\hline Two-Year Credits Earned & 20 & 20.4 & 18.1 \\
\hline Four-Year Credits Earned & 22.5 & $6.5 * *$ & 30.9 \\
\hline Annual Hours of Training & 780 & 346.4 & 314.2 \\
\hline $\mathrm{X}^{2}$ Critical Value (95 percent) & & 7.82 & 7.82 \\
\hline \multicolumn{4}{|c|}{$\begin{array}{l}\text { Note: Each test is performed over } 3 \text { cells. The discrete outcomes can take a value of missing, zero, } \\
\text { or one. The continuous outcomes can take a value of missing, or a value above or below the } \\
\text { thresholds defined in the table. The thresholds are the median value of the variable being tested for } \\
\text { the ages most relevant to this study. For example, the wage threshold is the median value of wages } \\
\text { at age } 25 \text {. The college credit thresholds are the median values for credits at age } 19 \text { and } 20 . \\
\text { * indicates cannot reject model at the } 90 \text { percent confidence level } \\
\text { ** indicates cannot reject model at } 95 \text { percent confidence level }\end{array}$} \\
\hline
\end{tabular}




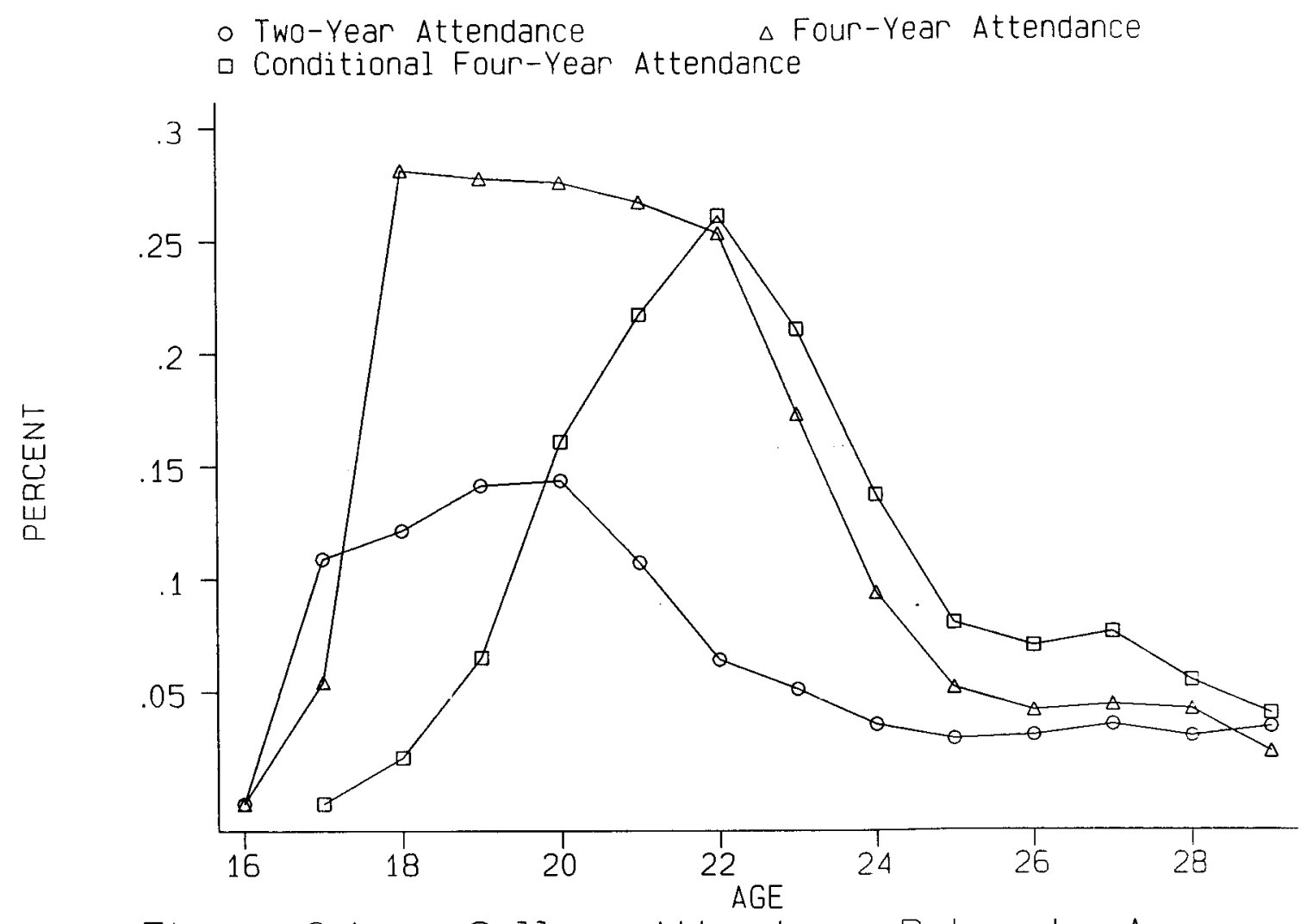

Figure 2.1 -- College Attendance Rates, by Age 


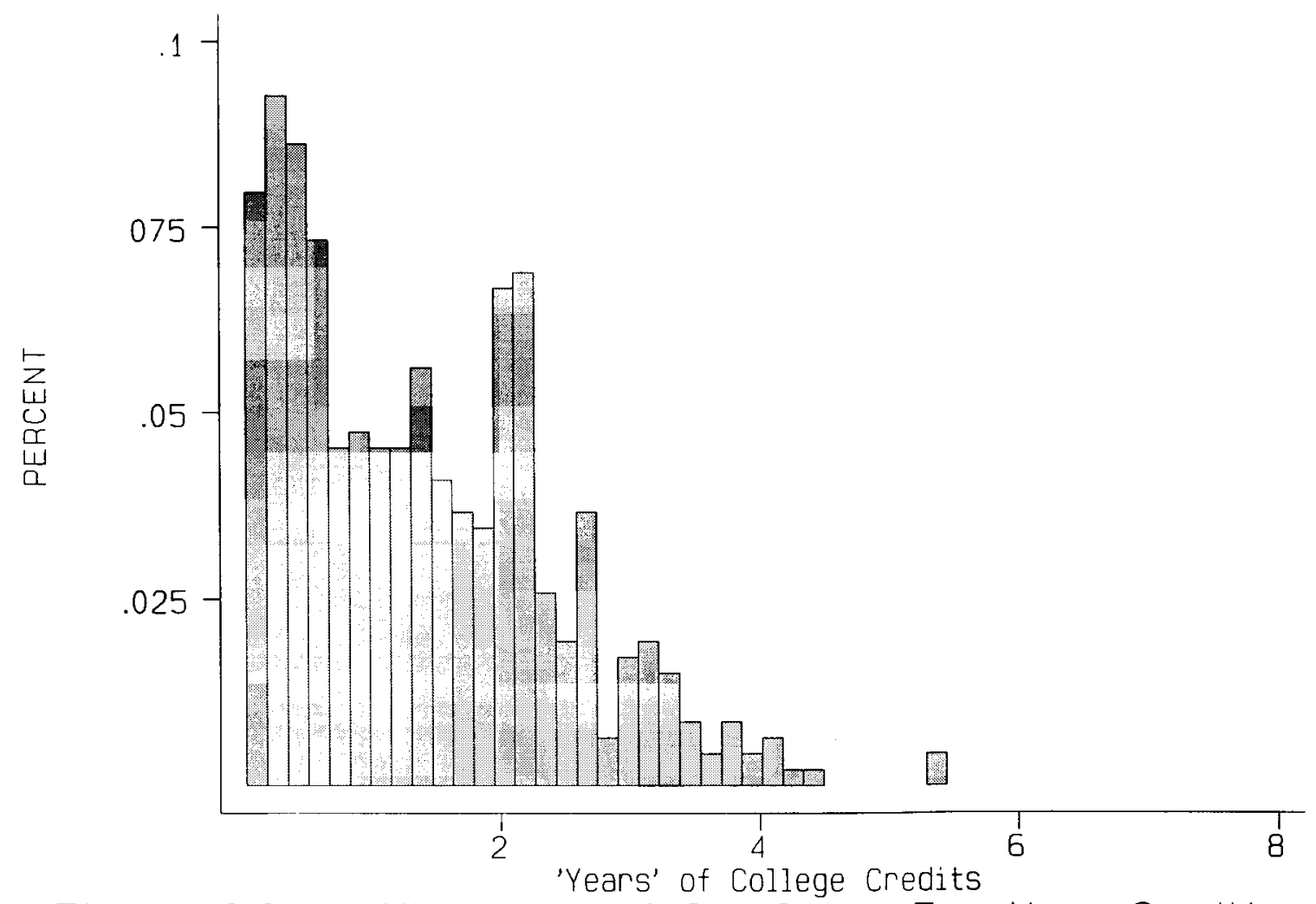

Figure 2.2 -- Histogram of Completed Two-Year Credits 


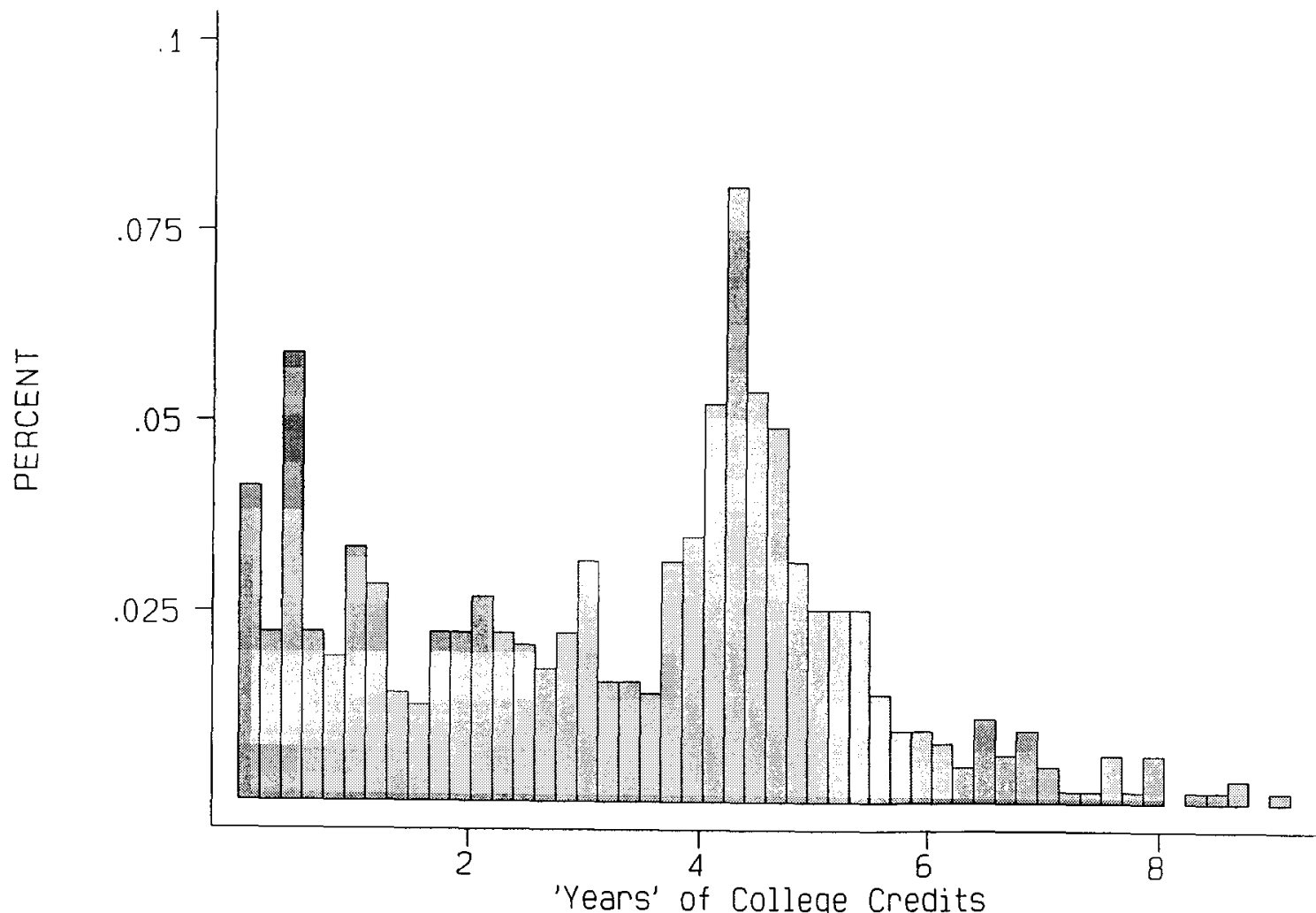

Figure 2.3 -- Historgram of Completed Four-Year Credits 


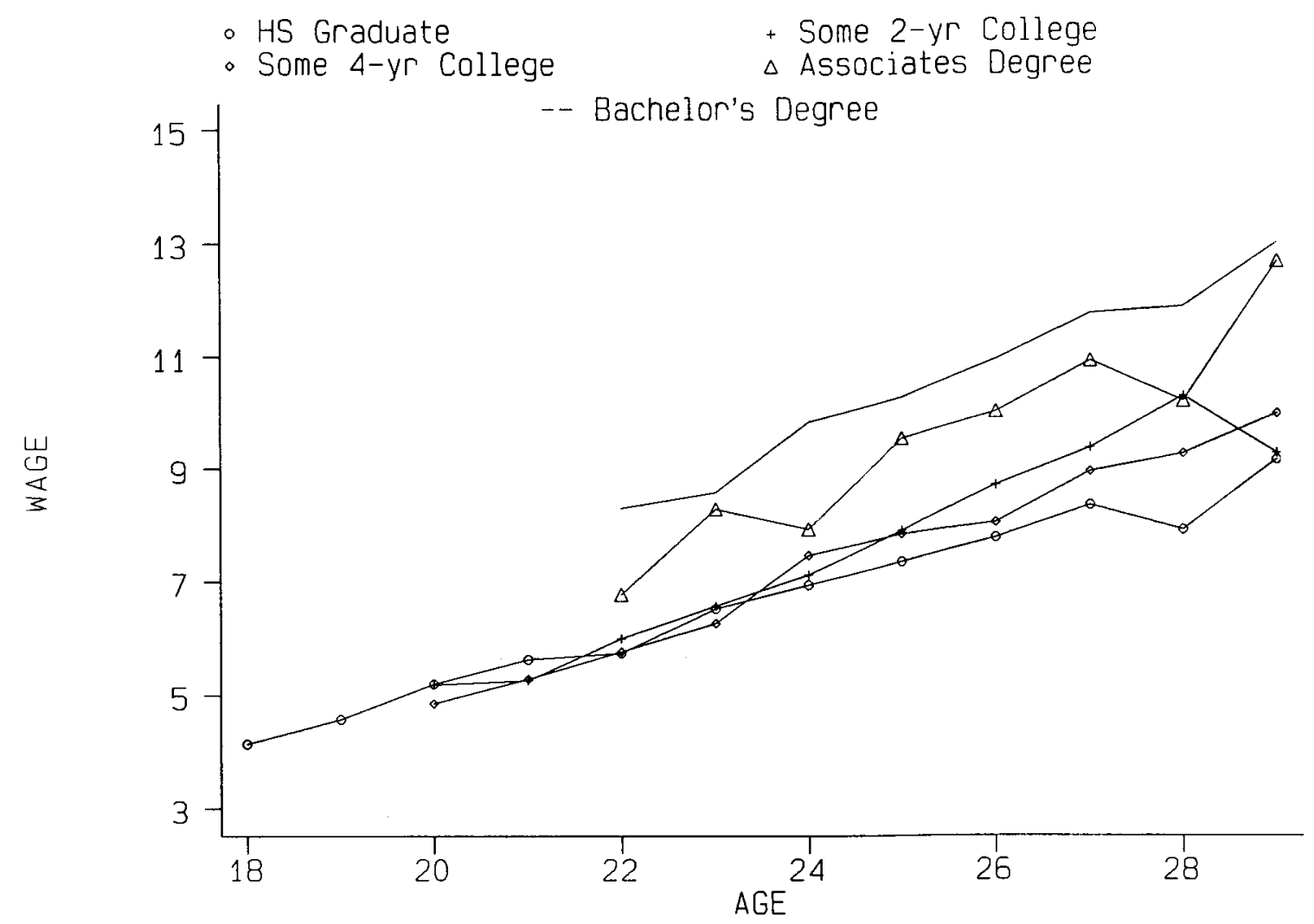

Figure 2.4 -- Median Wages by Education Group 


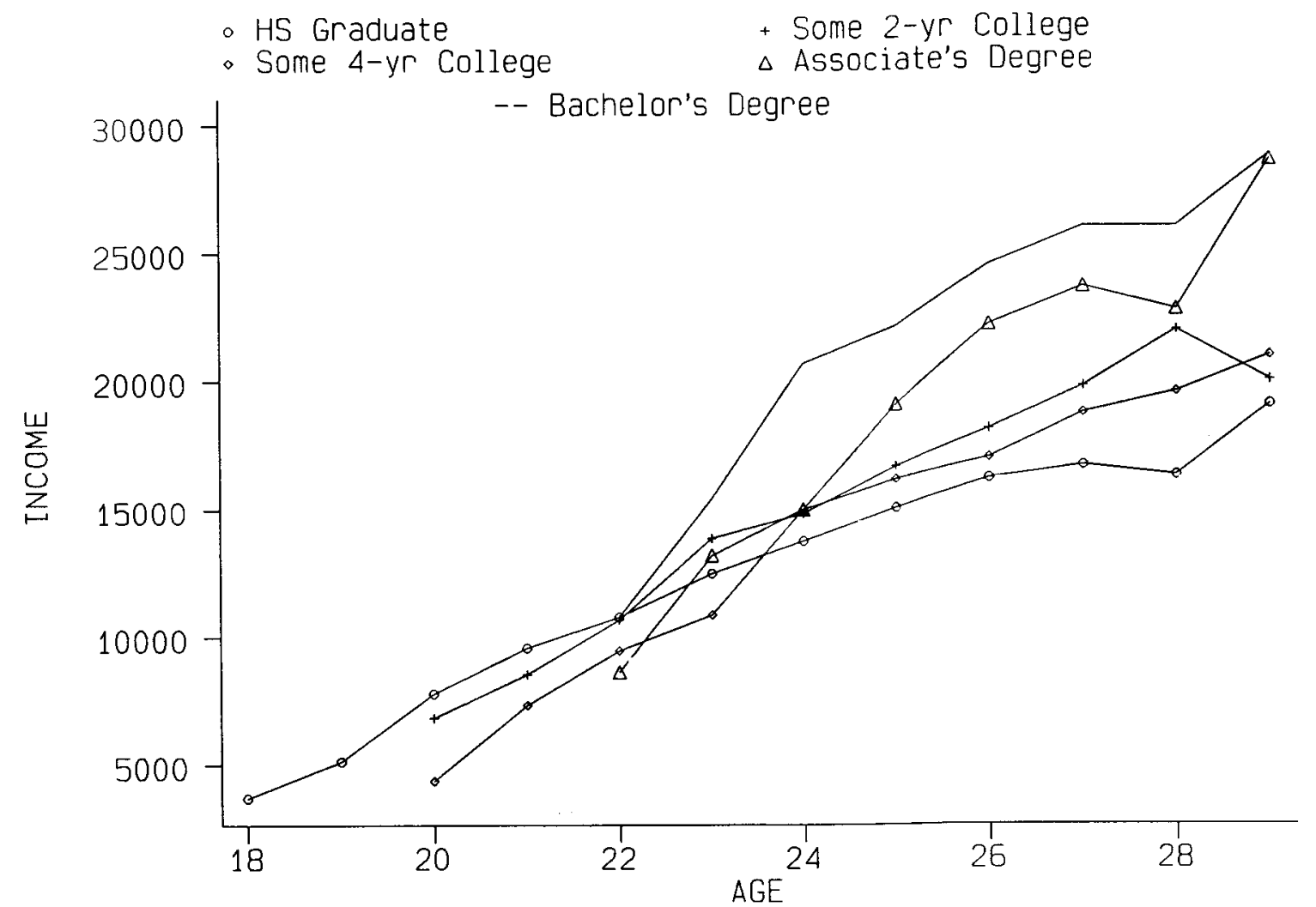

Figure 2.5 -- Median Annual Income by Education Group 


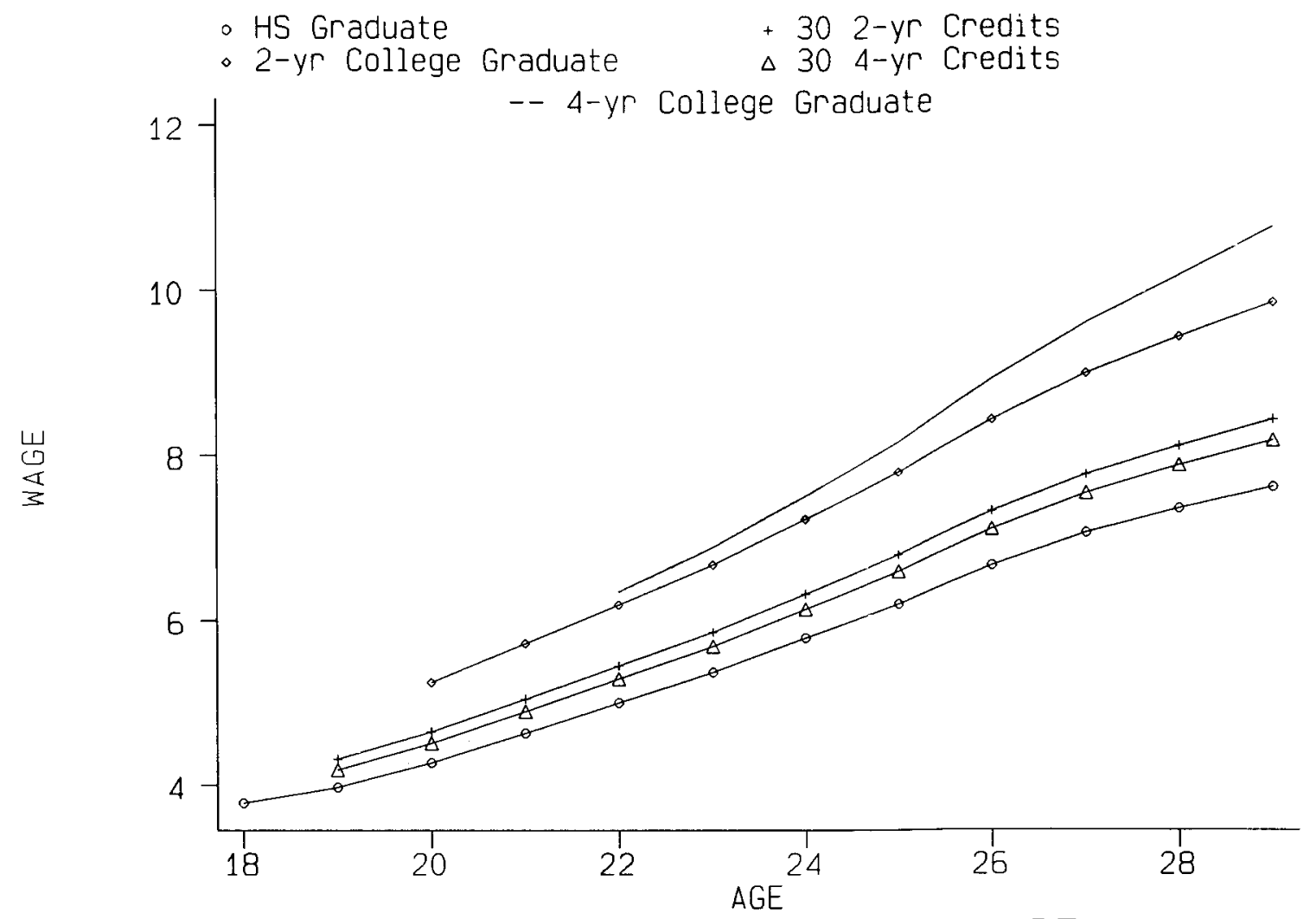

Figure 4.1 -- Predicted Wages Based on DF Model 


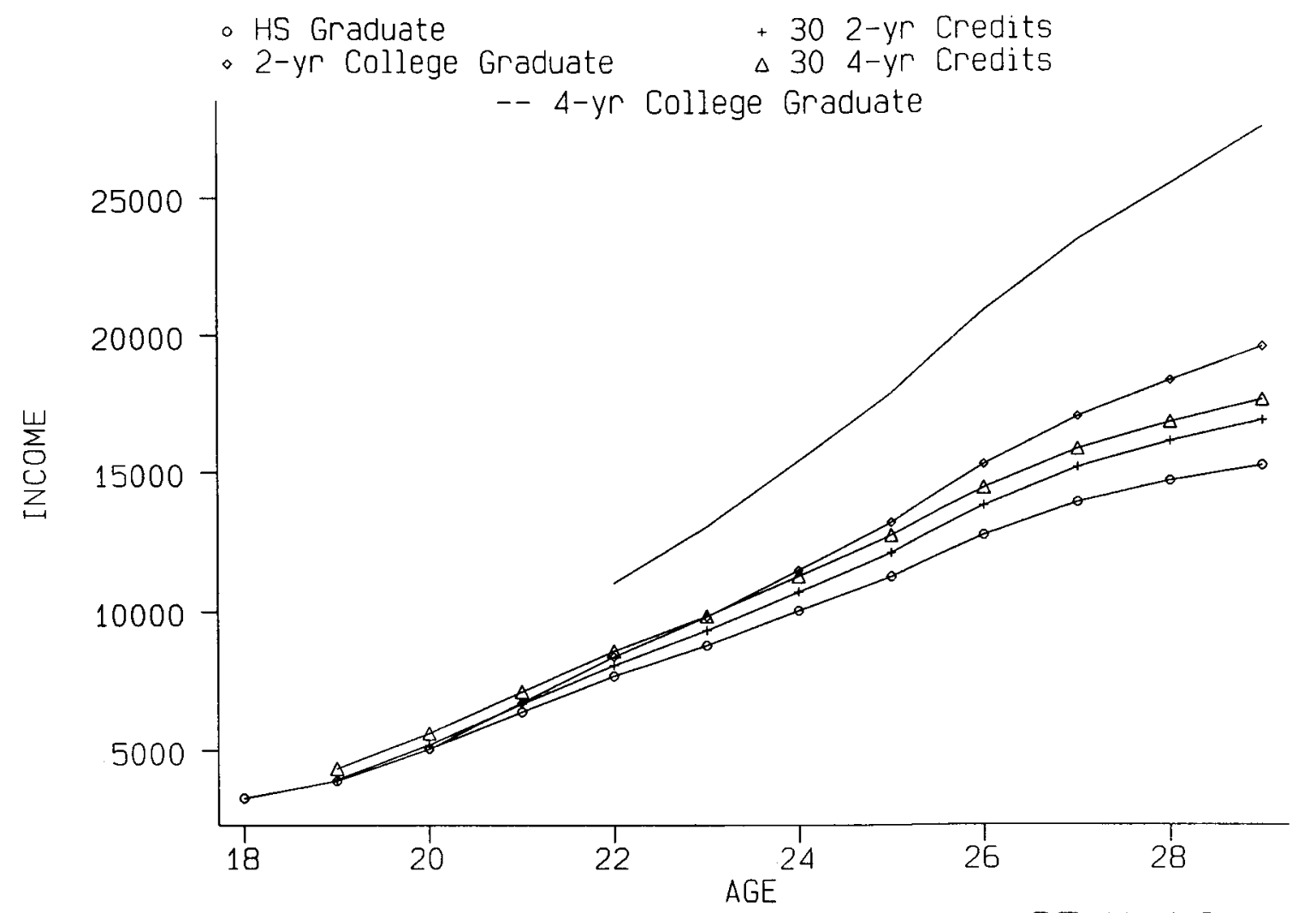

Figure 4.2 -- Predicted Income Based on DF Model 
Figure 4.3

Evaluation of Predicted College Attendance

(based on 50 simulations)

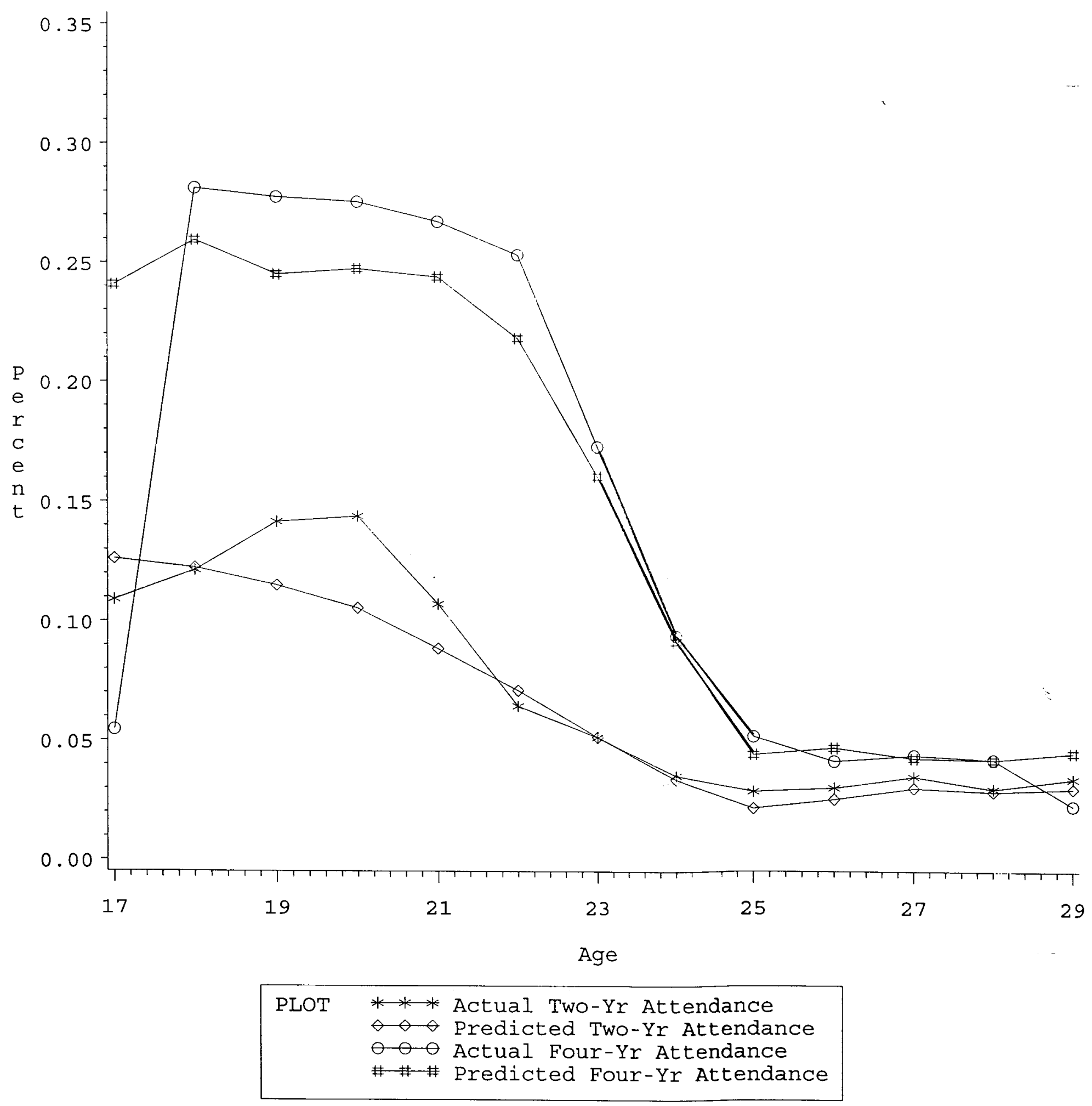


Figure 4.4

Evaluation of Predicted Annual Income (left scale) and Predicted Hourly wages (right scale)

(based on 50 simulations)

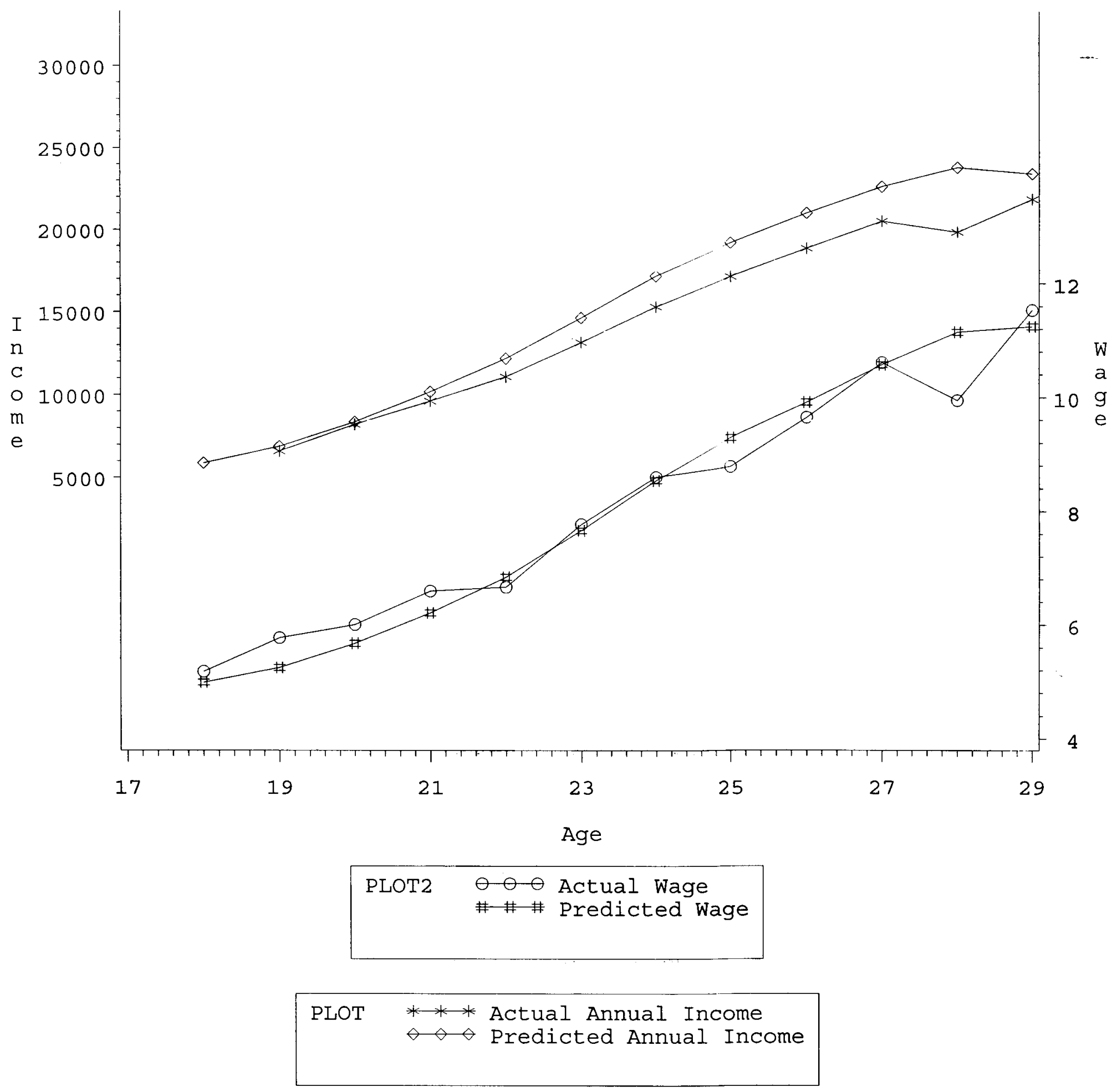


Figure 5.1

Simulated College Attendance Rates

50 Percent Reductions in College Tuition

(based on 50 simulations)

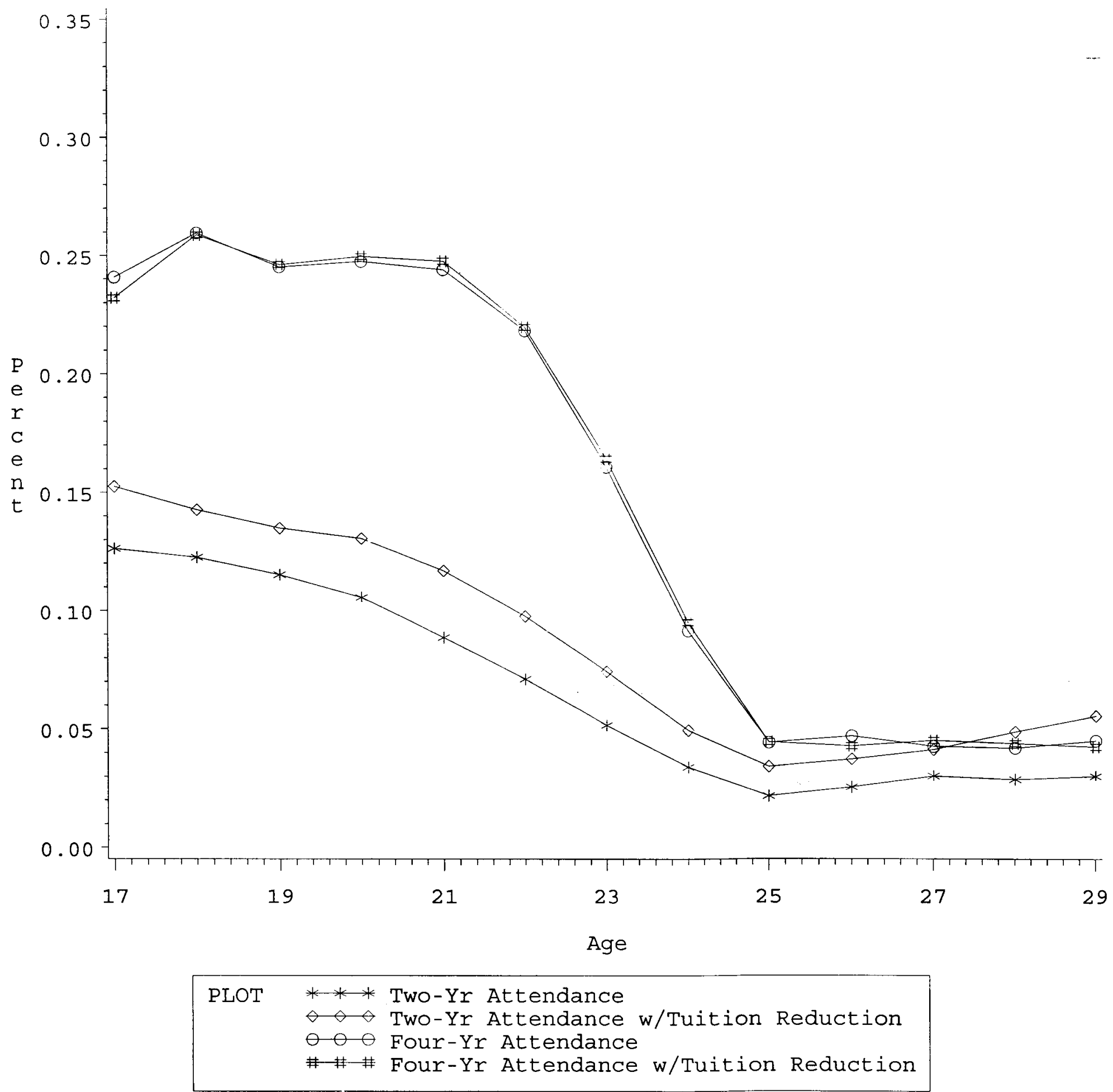




\section{Figure 5.2}

Simulated Annual Income (left scale) and Simulated Hourly Wages (right scale)

50 Percent Reductions in College Tuition

(based on 50 simulations)

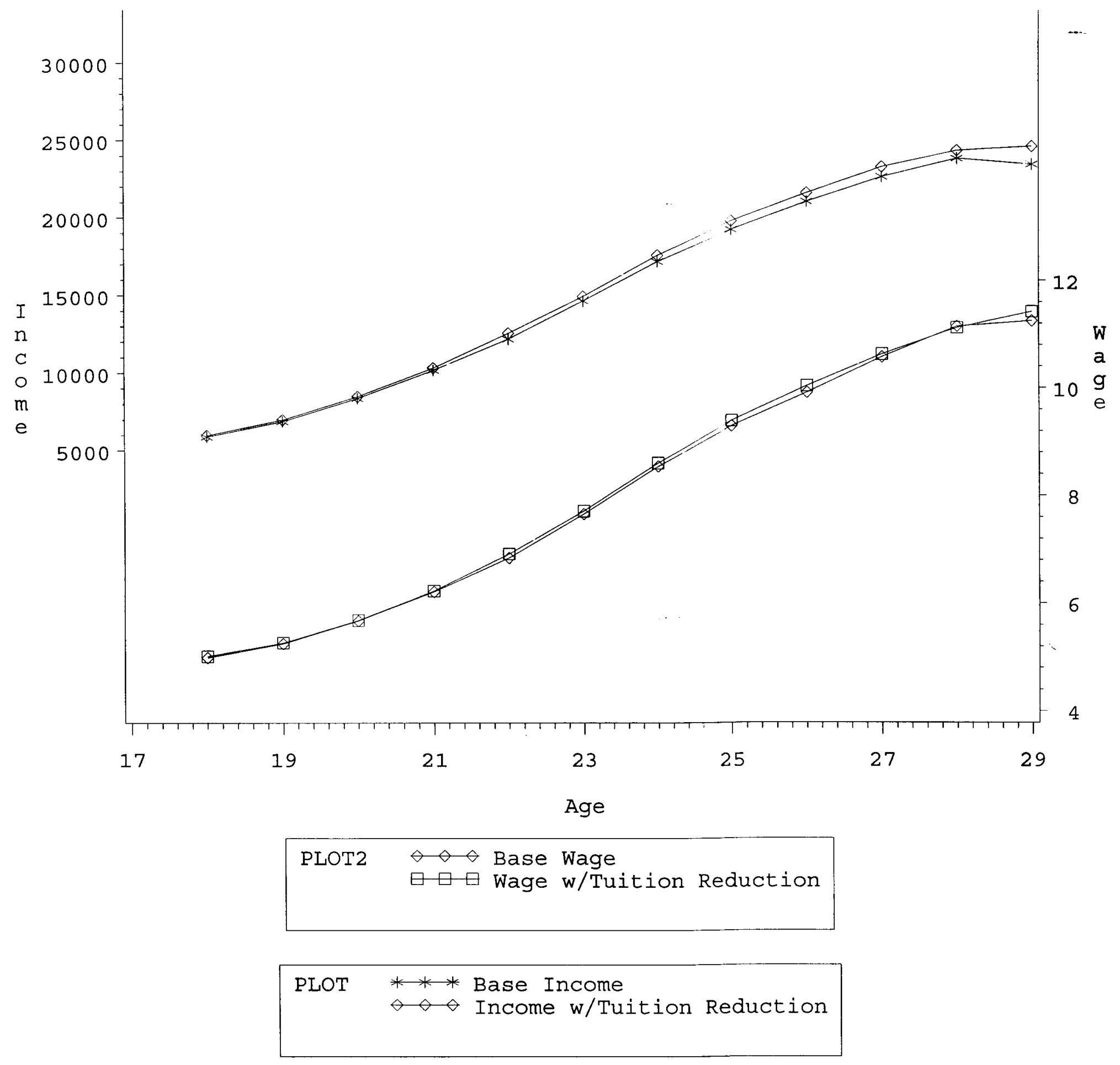

